\title{
Geopolitical Consequences of Resolving the Legal Status of the Caspian Sea: Security and Energy Aspects
}

\section{Geopolitičke posljedice rješavanja pravnog statusa Kaspijskog jezera: sigurnosni i energetski aspekti}

Caspian Sea is the largest water filled depression in the world. Before the dissolution of the Soviet Union it was shared by only two countries, but, since 1991, it has been shared by five states. This essay shows that there is a causal relation between regional instability, and the conflicting interests of countries of the region and world powers. These conflicting interests have caused the inability to reach an agreement on the legal status of the body of water, led to its militarization; and caused the conflict over the exploitation and transportation of oil and gas. Solving part of these problems in recent times has increased the stability of the region, but was also carried out in such a way that it increased the international influence of Russia, and prevented the entry of external forces into the region.

Key words: Caspian Sea, militarization, geopolitics, natural resources, international agreements
Kaspijsko jezero najveća je vodom ispunjena depresija na svijetu. Prije raspada SSSR-a dijelile su ga samo dvije države, a nakon 1991. na njegovim obalama nalazi se pet država. Ovaj rad pokazuje da postoji uzročno-posljedični odnos između sukobljenih interesa država regije i svjetskih sila te regionalne nestabilnosti. Sukobljeni interesi prouzročili su nemogućnost postizanja dogovora o pravnom statusu jezera, doveli do militarizacije jezera te izazvali sukob oko iskorištavanja i transporta nafte i plina. Rješavanje dijela tih problema u najnovije vrijeme povećalo je stabilnost regije, ali je i izvedeno na takav način da je povećalo međunarodni utjecaj Rusije i spriječilo ulazak izvanjskih sila u regiju.

Ključne riječi: Kaspijsko jezero, militarizacija, geopolitika, prirodni resursi, međunarodni ugovori 


\section{Introduction}

Economic development in the modern world is still significantly dependent on natural resources. Their importance has increased significantly in the $21^{\text {st }}$ century, as the ability to control them guarantees economic growth, political growth, and development. Many natural resources are in limited supply, particularly oil and natural gas, which increases their value, but also increases the potential for conflict between states over modes of their control and exploitation. The modern world is characterized by geopolitics of resources, where natural resources are becoming an increasingly important factor of instability between states seeking to establish their own share of dominance over oil fields, water, or gas.

The Caspian region is an area that is characterized by the growing importance of geopolitics of resources, especially after the fall of communism and the disintegration of the USSR. It has become the focal point of conflict between the different countries which use it, and external actors who are trying to break into this area. Many authors like Peimani (2009), Rubin (2006) and Megoran (2004) have pointed out that the main factors of its instability have been caused by political-ethnic conflicts, political-economic transformations after the collapse of the USSR, and the emergence of authoritarian regimes. These factors are undoubtedly the cause of its instability; however, this essay is based on the view that, in a world that is dependent on energy sources, natural resources have become an increasingly important factor of the conflict between countries. Their importance is especially visible in regions marked by poverty and frequent conflicts, where their possession is the only way to achieve or preserve a certain level of economic growth and the consolidation of national independence. Therefore, this essay places the oil, gas, and military significance of the Caspian Sea, as significant factors of interstate relations in the Caspian region, at the center of the research. Consequently, the essay is based on the hypothesis that in the modern era, in which earnings from natural resources are crucial for the economic growth of many countries, the conclusion of the preliminary agreement about the legal status of the Caspian Sea in 2014 is a factor which has stabilized the region and has had wider geopolitical consequences in terms of spreading Russian influence to the Middle East. The hypothesis will be tested by analyzing three key problems of the Caspian region: the reaching of an agreement on the legal status of the Caspian Sea; the

\section{Uvod}

Gospodarski razvoj suvremenog svijeta još uvijek bitno ovisi o prirodnim resursima. Njihova važnost osjetno se povećala u 21. stoljeću jer raspolaganje i kontrola nad njima jamče gospodarski i politički rast i razvoj. Mnogi prirodni resursi imaju ograničene zalihe, posebice nafta i prirodni plin, što povećava njihovu vrijednost, ali ujedno i mogućnost sukoba među državama oko načina njihove kontrole i iskorištavanja. Suvremeni svijet obilježen je geopolitikom resursa, gdje prirodni resursi postaju sve važniji čimbenik nestabilnosti između država koje nastoje uspostaviti vlastitu prevlast nad izvorima nafte, vode ili plina.

Kaspijska regija jedno je od područja u kojima raste važnost geopolitike resursa, posebice nakon pada komunizma i dezintegracije SSSR-a. Ona postaje žarište različitih sukoba između država koje ju čine, ali i vanjskih aktera koji se nastoje probiti na to područje. Mnogi autori poput Peimania (2009), Rubina (2006) i Megorana (2004) istaknuli su da su glavni čimbenici njezine nestabilnosti bili uzrokovani političko-etničkim sukobima, političko-ekonomskim transformacijama nakon raspada SSSR-a i nastankom autoritarnih režima. Ti čimbenici nesumnjivo jesu uzroci njezine nestabilnosti, ali ovaj rad polazi od stajališta da se u svijetu ovisnom o energentima prirodni resursi oblikuju u sve značajniji čimbenik sukoba među zemljama. Njihova važnost posebice je vidljiva u regijama obilježenima siromaštvom i čestim sukobima, gdje je njihovo posjedovanje jedini način za ostvarivanje ili očuvanje određenoga gospodarskog rasta i učvršćenje nacionalne neovisnosti. Ovaj rad zbog toga u središte istraživanja stavlja naftu i plin te vojno značenje Kaspijskog jezera kao značajne čimbenike međudržavnih odnosa u kaspijskoj regiji. Sukladno tome rad polazi od hipoteze da je u suvremeno doba, u kojemu je zarada od prirodnih resursa presudna za gospodarski rast mnogih zemalja, sklapanje preliminarnog sporazuma o pravnom statusu Kaspijskog jezera iz 2014. čimbenik koji stabilizira regiju i ima šire geopolitičke posljedice u obliku širenja ruskog utjecaja prema Bliskom istoku. Hipoteza će se testirati analizom triju ključnih problema kaspijske regije: postizanje dogovora o pravnom statusu Kaspijskog jezera, 
militarization of the region and the geopolitical role of Russia; and the exploitation and transport of oil and gas as the most important natural resources.

\section{Geopolitical interests in the Caspian region}

In the 1990s, extreme right-wing Russian politician Vladimir Zhirinovsky published the book "The Last Dash to the South" (Žirinovski, 1994). He put forward the idea of the expansion of Russia into territories that once belonged to the Russian Empire, but also of its spread to the southern, warm seas whereby Russia would annex some countries and thus push its borders to the Persian Gulf. Although neither Yeltsin nor Putin's policy has spread Russian borders (with the exception of the Crimea), Putin has sought to strengthen the international position of Russia and match the military might of the West, present on Russia's borders. In particular, this has been most important in the so-called "near abroad", i.e. in countries that were part of the USSR until 1991.

Russia failed to prevent the expansion of NATO into the Baltic States, but it tried to prevent its spread to Ukraine and Georgia. This was done by encouraging the secession of parts of their territories, resulting in the independent states - Abkhazia and South Ossetia - and with the annexation of Crimea. By expanding into these countries, NATO would risk war with Russia, because of Russia's control of parts of Ukrainian and Georgian territory. In such a case, NATO would, according to its own rules, have to intervene militarily on Georgia's and Ukraine's behalf. In other parts of the "near abroad" the US has sought to deploy its military forces and begin economic and military cooperation. This has happened in two areas: the eastern part of the Caucasus, and in part of Central Asia. Russia has never looked kindly on such American politics, but in the early 2000s it agreed to the American deployment in Central Asia, as Russia tried to connect the war in Afghanistan with its struggle in the North Caucasus, i.e. in Chechnya and Dagestan. However, interests soon changed and the Kremlin sought to expel the Americans from the region. Due to its pressure on the governments of the countries in question, the US has had to leave their bases in these countries. A similar situation also happened in Azerbaijan, which had got patrol boats from the US (Bahgat, 2002, 282), but greater military cooperation between two countries has not since been achieved. militarizacija regije i geopolitička uloga Rusije te iskorištavanje i transport nafte i plina kao najvažnijih prirodnih resursa.

\section{Geopolitički interesi u kaspijskoj regiji}

Ekstremno desni ruski političar Vladimir Žirinovski izdao je devedesetih godina 20. stoljeća knjigu Posljednji skok na jug (Žirinovski, 1994). U njoj je iznio ideju o širenju Rusije na teritorije koji su nekad pripadali Ruskom Carstvu, ali i o širenju prema južnim, toplim morima u kojemu bi Rusija anektirala neke zemlje i time izbila na Perzijski zaljev. Iako ni Jeljcinova ni Putinova politika nisu smjerale širenju ruskih granica (s izuzetkom Krima), Putin je nastojao ojačati međunarodni položaj Rusije i parirati vojnoj moći Zapada, koji se počeo približavati ruskim granicama. Naročito $m u$ je to bilo važno učiniti u tzv. bliskom susjedstvu, odnosno u zemljama koje su do 1991. bile dio SSSR-a.

Rusija nije uspjela spriječiti proširenje NATO-a na baltičke zemlje, ali je nastojala onemogućiti njegovo širenje na Ukrajinu i Gruziju. To je činila odvajanjem dijela njihova teritorija u samostalne države - Abhaziju i Južnu Osetiju - odnosno aneksijom Krima. Širenjem na te zemlje NATO bi riskirao rat s Rusijom jer bi zbog njezine kontrole dijela ukrajinskoga i gruzijskog teritorija morao, prema vlastitim pravilima, vojno intervenirati u njihovu korist. U drugim dijelovima bliskog susjedstva $\mathrm{SAD}$ je nastojao razmjestiti svoje vojne snage i započeti ekonomsku i vojnu suradnju s tim zemljama. To se dogodilo na dva područja: u istočnom dijelu Kavkaza i u dijelu Srednje Azije. Rusija nikada nije bila blagonaklona prema takvoj američkoj politici, ali je u prvim godinama 21. stoljeća pristala na američko pozicioniranje u Srednjoj Aziji jer je rat u Afganistanu nastojala povezati sa svojom borbom na sjevernom Kavkazu, tj. u Čečeniji i Dagestanu. No interesi se uskoro mijenjaju te je Kremlj nastojao izbaciti Amerikance iz regije. Zbog njegova pritiska na vlade tih zemalja SAD je morao napustiti baze na njihovu teritoriju. Slična je situacija bila i s Azerbajdžanom, koji je od SAD-a dobio patrolne brodove (Bahgat, 2002, 282), ali veća vojna suradnja tih dviju zemalja nikada nije postignuta.
Geopolitical

Consequences of Resolving the

Legal Status of

the Caspian Sea:

Security and Energy Aspects

Geopolitičke posljedice rješavanja pravnog statusa Kaspijskog jezera: sigurnosni i energetski aspekti 
The result of the US-Russia game in the region is strongly dependent on resolving the legal status of the Caspian Sea. The largest enclosed body of water on Earth has five countries on its shores that all have different views on how the problem of its legal status should be resolved, following the collapse of the Soviet Union. The interests of these countries can be classified into two groups: national security; and economic exploitation. However, the interests of bigger countries, like Russia and Iran, are also connected with broader geopolitical consequences. Although it has the shortest stretch of coastline in relation to the other four countries, the importance of Iran in international relations makes it an important player in the region. Together with Russia, it shares a similar view about the need to limit or completely suppress American influence in this part of the world. Despite tense relations with neighboring Azerbaijan, which came to the fore in 2001 in an incident in the disputed part of the Sea (Bahgat, 2002, 273; Rabinowitz et al., 2004, 32), the main problem for Iran has been the US presence in the region. Poor relations since the Revolution of 1979 have remained the same through present times, and even diplomatic reconciliation between the two countries, from 2015 under the Obama administration, did not permanently resolve tension. Another problem is Turkish involvement in regional relations. Due to its great power in the Middle East and the soft power that it exercises, Turkey is rival to Russia and Iran in wielding influence over the five Turkic countries of Central Asia and the Caucasus. Turkish-Iranian relations have often been poor in the past, but there were also periods of intensive cooperation. This is evident in modern times, as Turkey is getting about a third of its oil imports from Iran (Flanagan, 2013, 171); but, on the other hand, these two countries have different attitudes regarding policy toward the Middle Eastern countries. Their relations are further complicated due to their different foreign policy strategies toward Armenia and Azerbaijan. Although cultural reasons are in favor of good cooperation between both aforementioned countries and Azerbaijan (Sadri, 2012), Turkey has good relations with Azerbaijan, while Iran has good relations with Armenia - Azerbaijan's rival. Therefore, Iran's interest in resolving the status of the Sea in its favor is not merely in taking economically important sea-bed oil and gas fields from Azerbaijan, but also to weaken the role of that country in the region, and thereby weaken Turkey's influence in the region. Although Russian-Iranian relations in the past 25 years were of varying quality, the
Rezultat američko-ruske igre u regiji bitno ovisi o rješenju pravnog statusa Kaspijskog jezera. Ta najveća zatvorena vodena površina na Zemlji ima na svojim obalama pet zemalja, koje su nakon raspada SSSR-a imale različit stav o tome kako bi trebalo riješiti problem njegova pravnog statusa. Interesi tih zemalja mogu se svrstati u dvije skupine: nacionalna sigurnost i ekonomsko iskorištavanje, ali interesi velikih zemalja Rusije i Irana povezani su i sa širim geopolitičkim posljedicama. Iako zauzima najmanji dio obale jezera u odnosu prema ostale četiri zemlje, važnost Irana u međunarodnim odnosima čini ga važnim akterom u regiji. Zajedno s Rusijom ima sličan stav o tome da treba ograničiti ili potpuno suzbiti američki utjecaj u tom dijelu svijeta. Unatoč zategnutim odnosima sa susjednim Azerbajdžanom, koji su došli do izražaja i 2001. prilikom incidenta na spornom dijelu jezera (Bahgat, 2002, 273; Rabinowitz i dr., 2004, 32), glavni problem za Iran ipak je bila američka prisutnost u regiji. Loši odnosi od Revolucije iz 1979. ostali su takvi do danas te čak ni diplomatsko smirivanje problema između dvije zemlje koje je učinjeno 2015. pod Obaminom administracijom nije trajno riješilo napetost između njih. Drugi je problem tursko upletanje u regionalne odnose. S obzirom na svoju veliku moć u bliskoistočnim procesima i soft powver koji ima na pet turkijskih zemalja Srednje Azije i Kavkaza, Turska je takmac Rusiji i Iranu za postizanje utjecaja nad tim zemljama. Tursko-iranski odnosi u povijesti često su bili loši, ali su postojala i razdoblja intenzivne suradnje. To je vidljivo i u suvremeno doba, kada Turska oko trećinu svojeg uvoza nafte dobiva iz Irana (Flanagan, 2013, 171), ali s druge strane dvije zemlje imaju različit stav u vezi s politikom prema bliskoistočnim zemljama. Njihovi odnosi dodatno su komplicirani različitim vanjskopolitičkim strategijama Turske i Irana prema Armeniji i Azerbajdžanu. Iako kulturološki razlozi idu u prilog dobroj suradnji obiju zemalja s Azerbajdžanom (Sadri, 2012), Turska ima dobre odnose s njim, dok Iran ima dobre odnose s Armenijom. Zbog toga iranski interes za rješenje statusa jezera u vlastitu korist nije samo u tome da od Azerbajdžana uzme naftna i plinska polja na dnu jezera zbog njihove ekonomske važnosti, nego i zbog toga da se oslabi uloga te zemlje, a time i Turske u cijeloj regiji. Premda su rusko-iranski odnosi u proteklih 25 godina bili 
Russian alliance with Armenia, and some other factors such as the proximity of the Caspian Sea to the presence of external forces, eased the conclusion of an agreement on the status of the Sea between Russia and Iran. This was clear from their similar views on the establishment of a condominium over the Caspian Sea in one period, and the signing of the agreement of 2008 on the joint development of Iranian oil and gas reserves (Flanagan, 2013, 173).

Interests of the other three Caspian countries differ from Russian and Iranian interests primarily because of their lesser impact in international relations. They, like Russia, accept realism in international relations, but for other reasons. While Russia has been attempting to restore its status as a world power, the three Caspian countries have made efforts to maximize the development of their own economies, and, in particular, to avoid falling under the influence of Russia, China, or the United States. In addition to being small (Kazakhstan in population, if not in territory), and having weaker economies than Russia and Iran, an essential feature of these countries is the fact that they do not have access to the world's oceans. The only possibility of going from the Caspian Sea into one of the world's oceans is to go, via river, through another country. Therefore, the importance of resolving the legal status of the Sea for them is not in achieving security from the United States, but primarily to secure themselves from their two big Caspian neighbors - Russia and Iran. They would, more than Russia and Iran, welcome the possibility that other countries and world powers be present in this area, as this would create a counterweight against the two big Caspian countries, and would establish a more favorable negotiating position in possible bilateral negotiations therewith.

\section{Problem of the legal status of the Caspian Sea}

The Caspian Sea is the largest enclosed body of water in the world, and is separated by a large distance from the nearest ocean. The Sea is rich in oil and natural gas, and with a large number of animal species, especially sturgeon - which are crucial for the production of caviar. As such, the Sea represents a prolific area for the realization of economic and political growth in the region. The US Energy Information Administration (EIA) estimates that the Caspian basin contains 48 billion barrels of oil and različite kvalitete, rusko savezništvo s Armenijom i neki drugi čimbenici poput zatvaranja Kaspijskog jezera za prisutnost vanjskih sila stvaraju temelje za lakše postizanje sporazuma o statusu jezera između Rusije i Irana. To je bilo jasno u njihovu sličnom stavu u vezi s uspostavom kondominija nad Kaspijskim jezerom u jednom razdoblju te u potpisivanju sporazuma 2008. o zajedničkom razvoju iranskih naftnih i plinskih rezervi (Flanagan, 2013, 173).

Interesi preostalih triju kaspijskih zemalja razlikuju se od ruskih i iranskih prije svega zbog njihova manjeg utjecaja u međunarodnim odnosima. One, poput Rusije, prihvaćaju realističku politiku u međunarodnim odnosima, ali zbog drugih razloga. Dok Rusija to čini nastojeći obnoviti svoj status svjetske sile, tri kaspijske zemlje to čine nastojeći maksimizirati razvoj vlastitih gospodarstava i naročito izbjeći padanje pod utjecaj Rusije, Kine ili SAD-a. Osim što su manje (Kazahstan brojem stanovnika, ako ne i veličinom) te imaju slabija gospodarstva od Rusije i Irana, bitno obilježje tih zemalja jest $\mathrm{i}$ to što one nemaju izlaz na svjetska mora. Jedina mogućnost da izađu iz Kaspijskog jezera na neki svjetski ocean jest preko trećih zemalja. Zbog toga rješavanje pravnog statusa jezera za njih nije važno zbog osiguravanja od SAD-a, nego prije svega zbog mogućnosti da se osiguraju od svoja dva velika kaspijska susjeda. Njima bi, više nego Rusiji i Iranu, odgovarala mogućnost da i druge zemlje i svjetske sile budu prisutne na tom području jer bi se time stvorila protuteža dvjema velikim kaspijskim zemljama te bi imale povoljnije pregovaračke pozicije $u$ eventualnim bilateralnim pregovorima s te dvije zemlje.

\section{Problem pravnog statusa Kaspijskog jezera}

Kaspijsko jezero najveće je na svijetu, s relativno velikom udaljenošću od najbližeg oceana. Jezero je bogato naftom i prirodnim plinom te je uz veliki broj životinjskih vrsta, posebice jesetre, važne za proizvodnju kavijara, plodno područje za ostvarivanje gospodarskoga i političkog rasta regije. Američka Administracija za energetske informacije (EIA) procjenjuje da kaspijski bazen sadržava 48 milijardi barela nafte i 292 bilijuna $\mathrm{m}^{3}$ prirodnog plina u dokazanim i mogućim rezervama, od
Geopolitical

Consequences of Resolving the

Legal Status of

the Caspian Sea:

Security and Energy Aspects

Geopolitičke posljedice rješavanja pravnog statusa Kaspijskog jezera: sigurnosni i energetski aspekti 
292 billion $\mathrm{m}^{3}$ of natural gas in proven and probable reserves, of which almost $75 \%$ of oil and $67 \%$ natural gas sources are located within 100 miles from the coast (Overview, 2015). These resources make the Caspian Sea a prime geopolitical and energy center that serves superpowers as an ideal place for diversifying natural resources (Klare, 2005).

Since the collapse of the USSR in 1991 it has been difficult to reach agreements on cooperation, and exploitation of natural resources in the region. One of the reasons for this was the unresolved legal status of the Sea. Efforts to solve this problem were unsuccessful until recently because the coastal states had different positions and interests. Before 1991 the Sea was divided between two countries, the USSR and Iran, and its status was regulated by the Treaty of Friendship of 1921 and the Treaty on Trade and Navigation of 1940. The Treaty of 1954 established the land border between the two countries, but no borders on the Sea (Mehdiyoun, 2000, 5; Butler, 1969) or on the sea floor (Zimnitskaya and von Geldern, 2011, 7). With the emergence of new states in the Caspian basin in 1991, this problem became magnified and coastal states were required to define the legal status in order to determine if it was a sea or a lake. ${ }^{1}$ It was a serious problem, considering that its features "have prevented its ready geological and legal classification" (Mehdiyoun, 2000, 4). The problem of a legal definition of the Sea primarily involves the interconnection of its legal status and natural resources, and the changes in geopolitical influence that this sort of resolution would have. Zimnitskaya and von Geldern $(2011,2)$ point out that "if the Caspian Sea is an inland sea, its waters and resources would be regulated by the United Nations Convention on the Seas (hereinafter UNCLOS), ${ }^{2}$ open to all the littoral states, and accessible to these states and the great multinational petroleum corporations. If the Caspian is just a lake, its waters and resources kojih su gotovo $75 \%$ izvora nafte i $67 \%$ izvora prirodnog plina smješteni unutar sto milja od obale (Overview, 2015). Takvi resursi čine Kaspijsko jezero prvorazrednim geopolitičkim i energetskim središtem koje velesilama služi kao idealno mjesto za diversifikaciju izvora prirodnih resursa (Klare, 2005).

Od raspada SSSR-a 1991. teško su se postizali sporazumi o suradnji i iskorištavanju prirodnih resursa u regiji, a jedan od razloga jest neriješen pravni status jezera. Sve do najnovijeg vremena nastojanja da se riješi taj problem bila su neuspješna zbog različitih stavova i interesa obalnih država o tome. Ono je prije 1991. bilo podijeljeno između dvije strane, SSSR-a i Irana, te je njegov status bio uređen Ugovorom o prijateljstvu iz 1921. i Ugovorom o trgovini i navigaciji iz 1940. Ugovor iz 1954. utvrdio je kopnenu granicu između dviju država, ali ne i granicu na jezeru (Mehdiyoun, 2000, 5; Butler, 1969) i na njegovu dnu (Zimnitskaya i von Geldern, 2011, 7). Nastankom novih država u kaspijskom bazenu 1991. taj se problem povećava te su priobalne države zahtijevale da se definira pravni status kako bi se utvrdilo je li to jezero ili more. ${ }^{1}$ To je bio ozbiljan problem s obzirom na to da njegove karakteristike „onemogućuju jasnu geološku i pravnu klasifikaciju" (Mehdiyoun, 2000, 4). Problem pravne definicije jezera ponajprije se sastoji u međusobnoj povezanosti njegova pravnog statusa i prirodnih resursa, ali i geopolitičkog utjecaja koje to rješenje nosi sa sobom. Zimnitskaya i Von Geldern ističu da „ako je Kaspijsko jezero unutarnje more, njegove vode i resursi bili bi regulirani Konvencijom Ujedinjenih naroda o pravu mora (nadalje UNCLOS), ${ }^{2}$ otvoreni svim priobalnim državama i dostupni tim državama i velikim multinacionalnim naftnim korporacijama. Ako bi Kaspij bio samo jezero, njegove vode i resursi trebali bi biti raspodijeljeni samo između priobalnih država i ne-

\footnotetext{
1 For the sake of consistency in the essay authors use terms "Caspian Sea" or "the Sea".

1 U ovom radu zbog dosljednosti izražavanja autorâ upotrebljava se termin „Kaspijsko jezero”, a ne „Kaspijsko more”.

2 Convention (Eng. Acronym UNCLOS) was adopted in Montego Bay, Jamaica, 10 December 1982. It regulates the rules, procedures and methods of cooperation between states over access to and use of the open sea and international waters (United Nations Convention on the Law of the Sea and Final Act of the Third United Nations Conference on the Law of the Sea with Annexes I-VII and with Annex and the Agreement Relating to the Implementation of Part XI of the United Nations Convention on the Law of the Sea of December 10th 1982).

2 Konvencija (engl. kratica UNCLOS) donesena je u Montego Bayu u Jamajci 10. prosinca 1982. Njome se uređuju pravila, postupci i načini suradnje između država u vezi s pristupom otvorenim morima i međunarodnim vodama i korištenjem njima (Konvencija Ujedinjenih naroda o pravu mora i Završni akt Treće konferencije Ujedinjenih naroda o pravu mora s Prilozima I. - VII. i Dodatkom i Sporazum o primjeni XI. dijela Konvencije Ujedinjenih naroda o pravu mora od 10. prosinca 1982.).
} 
should be divided by the littoral states, and are not open to the international community."

Russia exercised a key role in defining the legal status of the Sea. Although its foreign policy interests have changed over time, one of its interests was very clear from the beginning: to close the Sea to non-Caspian countries. Another major interest was to achieve a solution that would enable multilateral cooperation between the Caspian states, but in such way that Russia would enjoy the strongest influence. It challenged the stance to define the Caspian as an open sea, and thus enabling the application of UNCLOS, because this would prevent Russia's efforts to claim sovereignty over parts of the Sea that are located along its coastline, and open the possibility that the "Russian part" (and the rest of the Sea) would become available to the other states, representing a major blow to its economic plans (Zimnitskaya and von Geldern, 2011) and national security. Instead, it proposed the establishment of a condominium that would define the Caspian Sea as "a closed (inland or terminal) water body having no natural links with the world ocean. In legal terms it cannot be considered either as a sea or as a lake. In particular, it is not subject to the action of the 1982 UN Convention on the Law of the Sea" (Zonn, 2005, 249). This means that Russia accepted two options for the definition of the Caspian Sea: to be a closed sea (mare clausum) or a border lake (Makili-Aliyev, 2014, 31). Such solution of the legal status suited Russia because it would prevent interference from external factors in the Caspian region, and also prevent the efforts of Turkmenistan and Kazakhstan to use Russian waterways as international waterways to export their oil and gas to $\mathrm{Eu}-$ ropean markets. This would confirm its status as the strongest among the Caspian countries and would force the others to cooperate with Russia if they want to strengthen their foreign trade.

The interests of Kazakhstan were different. This country wanted the legal status of the Sea to be defined according to the principles of UNCLOS, which would make the Caspian an open sea. Such an attitude largely stems from the fact that the status of "open sea" would directly influence a change in the legal regime of the delta of the Volga River which flows into the Caspian Sea. Uibopuu (1995, 119) points out that "under international law, a river which dostupni međunarodnoj zajednici" (Zimnitskaya i von Geldern, 2011, 2).

Ključni položaj u definiranju pravnog statusa jezera imala je Rusija. Premda su se njezini vanjskopolitički interesi s vremenom mijenjali, jedan njezin interes bio je od početka vrlo jasan, a to je da jezero bude zatvoreno za nekaspijske zemlje. Drugi važan interes bio je da se postigne takvo rješenje koje bi omogućilo multilateralnu suradnju između kaspijskih država, ali tako da ipak ona ima najjači utjecaj u tome. Ona se protivila tome da se Kaspijsko jezero definira kao otvoreno more i time omogući primjena UNCLOS-a jer bi to onemogućilo njezina nastojanja da traži suverenitet nad dijelovima jezera koji se nalaze uz njezinu obalu i otvorila bi se mogućnost da „ruski dio" te vodene mase postane dostupan svim državama bez izlaska na more, što bi bilo veliki udarac njezinim gospodarskim planovima (Zimnitskaya i Von Geldern, 2011) i nacionalnoj sigurnosti. Umjesto toga predlagala je uspostavu kondominija koji bi definirao Kaspijsko jezero kao „zatvorenu (kopnenu ili terminalnu) vodenu masu koja nema nikakvih prirodnih poveznica sa svjetskim oceanima. U pravnom pogledu ne bi se moglo smatrati ni otvorenim morem ni jezerom. Posebice, nije podložan UN-ovoj konvenciji o pravu mora iz 1982. godine" (Zonn, 2005, 249). To znači da je Rusija prihvaćala dvije mogućnosti za definiciju Kaspijskog jezera, a to je da bude zatvoreno more (mare clausum) ili granično jezero (Makili-Aliyev, 2014, 31). Takvo rješenje pravnog statusa odgovaralo bi joj jer bi onemogućilo upletanja vanjskih čimbenika u kaspijsku regiju, a ujedno i nastojanja Turkmenistana i Kazahstana da se koriste ruskim vodenim putovima kao međunarodnim vodenim putovima za izvoz svoje nafte i plina na europska tržišta. To bi potvrdilo njezin najjači status među kaspijskim državama, koje bi morale surađivati s njom ako bi željele jačati svoju vanjskotrgovinsku razmjenu.

Interesi Kazahstana bili su drukčiji. Ta zemlja htjela je da pravni status jezera bude definiran prema načelima UNCLOS-a, što bi Kaspijsko jezero učinilo otvorenim morem. Takvo stajalište ponajviše proizlazi iz toga da bi status otvorenog mora izravno utjecao na promjenu pravnog režima delte rijeke Volge, koja se ulijeva u Kaspijsko jezero. Uibopuu ističe da se „prema međunarodnom pravu, rijeka koja plovi kroz više od jedne države treba
D. Boban

K. Lončar

Geopolitical

Consequences

of Resolving the

Legal Status of

the Caspian Sea:

Security and Energy Aspects

Geopolitičke

posljedice rješavanja pravnog statusa Kaspijskog jezera: sigurnosni i energetski aspekti 
flows through more than one state should be regarded as an international river, notwithstanding the fact that almost all of its waters are going through one state only. It is true that the delta of the Volga does not exactly touch the soil of Kazakhstan, but the river Akhtuba flows into the Caspian Sea through Kazakh territory, and the Volga and the Akhtuba are so intertwined that under international law they should be regarded as a single waterway system or, in the terms used by an authority of international waterways law, a hydrographical basin." (Uibopuu, 1995, 119) ${ }^{3}$ Such definition of the delta of Volga would change the regime of the Russian waterway Volga-Baltic Sea and would create a single waterway from Central Asia to the Baltic (Uibopuu, 1995, 119-120).

Russia, however, showed a certain flexibility. It abandoned the proposition on the condominium from late 1990s and started to conclude bilateral agreements which delimited the bottom of the Sea. The first was reached with Kazakhstan in 1998 and the second with Azerbaijan in 2001, on the basis of the median line principle (Rabinowitz et al., 2004, 31-32). This corresponded with a change in Russian foreign policy after 2000, from the period of geopolitical realism into pragmatic geo-economic realism, in which economic interests had a stronger role than before (Thorun, 2009, 10). Turkmenistan was less flexible. In 2003, it started negotiations with Kazakhstan about the demarcation of the Sea, but it was stopped because of the conflict with Azerbaijan over oil and gas fields "Azeri-Chirag-Guneshli” (Parkhomchik, 2015). Turkmenistan appeared as a factor of instability, because in 1993 it adopted a law that unilaterally declared its jurisdiction over the Sea out to 12 nautical miles (nm) extending from its coast (Hafezni et al., 2016, 183). This country also refused to sign any multilateral agreements on the division of the Sea's bottom and surface because of its foreign policy, described as closed, neutral, away from external initiatives, and away from participating in projects led by Russia (Assanbayev, 2014, 143). The official policy of Turkmenistan was the division of the Sea's bottom and surface into fully-independent national sectors, where particular parts of the bottom belong to each country, and this would also spread to the water surface and air space (Zonn, 2005). Turk- smatrati međunarodnom rijekom, bez obzira na to što sve njezine vode prolaze kroz samo jednu državu. Točno je da delta Volge ne dotiče tlo Kazahstana, ali rijeka Akhtuba ulijeva se u Kaspijsko jezero kroz kazački teritorij te su Akhtuba i Volga toliko isprepletene da se prema međunarodnom pravu trebaju smatrati jedinstvenim vodenim putom ili, $\mathrm{u}$ terminologiji upotrebljavanoj u pravu međunarodnih vodenih putova, hidrografskim bazenom" (Uibopuu, 1995, 119). ${ }^{3}$ Takva definicija delte Volge promijenila bi režim ruskoga vodnog puta Volga - Baltičko more i stvorila jedinstveni vodeni put od Srednje Azije prema Baltiku (Uibopuu, 1995, 119-120).

Rusija je, ipak, pokazivala i određenu fleksibilnost te je od prijedloga kondominija krajem devedesetih prešla na potpisivanje bilateralnih sporazuma kojima se razgraničavalo dno jezera. Prvo je s Kazahstanom postigla takav sporazum 1998., a potom i s Azerbajdžanom 2001. na temelju načela medijanskih linija (Rabinowitz i dr., 2004, 3132). To korespondira s promjenom ruske vanjske politike nakon 2000. iz razdoblja geopolitičkog realizma u pragmatični geoekonomski realizam, u kojemu ekonomski interesi imaju jaču ulogu nego prije (Thorun, 2009, 10). Turkmenistan je bio manje fleksibilan jer je još 2003. započeo pregovore s Kazahstanom oko razgraničenja na jezeru, ali ih je i zaustavio zbog spora s Azerbajdžanom oko naftnih i plinskih polja „Azeri-Chirag-Guneshli” (Parkhomchik, 2015). Turkmenistan se ovdje pokazuje kao čimbenik nestabilnosti jer je još 1993. zakonom jednostrano proglasio svoju jurisdikciju nad $12 \mathrm{~nm}$ od obale (Hafezni i dr., 2016, 183). Ta je zemlja usto odbijala potpisati bilo kakve multilateralne sporazume o podjeli dna i površine jezera zbog vanjske politike koju Assanbayev opisuje kao zatvorenu, neutralnu te udaljenu od vanjskih aktivnosti i sudjelovanja u projektima koje vodi Rusija (Assanbayev, 2014, 143). Službeni je stav Turkmenistana bio da bi podjela dna i površine jezera trebala biti određena prema potpuno neovisnima nacionalnim sektorima, gdje svakoj državi pripada određeni dio dna, a to bi se također proširilo na vodenu površinu i zračni prostor (Zonn,

3 Uibopuu twice refers to: J. A. Barberis, “International Rivers”, The Encyclopedia of International Law, Vol. IX, p. 212 and p. 216.

3 Uibopuu se dvaput referira na: J. A. Barberis, „International Rivers”, The Encyclopedia of International Law, Vol. IX, p. 212. i p. 216. 
menistan, and above all, Iran rejected a proposal from Kazakhstan and Russia on delimitation of the bottom of the Sea, based on the median line principle, that would give 29\% to Kazakhstan, 20\% to Azerbaijan, $16 \%$ to Russia, $21 \%$ to Turkmenistan and $14 \%$ to Iran (Winstone and Young, 2005, 11) as both countries wanted a larger share.

Bilateral agreements signed by Russia, Kazakhstan and Azerbaijan from 1998 to 2001, related to the bottom of the Sea but not to the surface. Russia has recently begun to argue that one part of the Sea should be under the joint control of five states (Zonn, 2005, 250). Demarcation of the Sea were to take place on the basis of the formation of "'national" or "coastal" zones extending from their respective shores" (Winstone and Young, 2005, 11). However, the main obstacle in the multilateral agreement was the extent of the national zones. Russia argued that national zones should extend to $15 \mathrm{~nm}$, while Azerbaijan, Kazakhstan and Turkmenistan wanted $40 \mathrm{~nm}$ (Winstone and Young, 2005,11). Kazakhstan and Turkmenistan prefer the larger scope of national zones in order to get greater access to natural resources or the possibility of drilling oil wells at the bottom of the Sea, which brings them into conflict with Russia, which seeks to control the larger "common area" of the Sea. Iran argued for joint management of the Sea, or at least the same share of the Sea for all coastal states (Bachmann, 2004). It also argued against a definition of the Caspian as a sea, because that would, among other things, enable the entry of the US Navy (Zimnitskaya and Geldern, 2011, 6). It disputes the Alborz/Alove oil field with neighboring Azerbaijan, much as Turkmenistan and Azerbaijan dispute some other oil fields (Bahman, 2004).

Significant progress in defining the status was achieved only at the Fourth Caspian Summit, held in 2014 in Astrakhan. Coastal countries agreed on the establishment of a national sovereignty in the zone extending $15 \mathrm{~nm}$ from the coast and the exclusive use of water and water resources extending a further $10 \mathrm{~nm}$ past that (Caspian Summit, 2014). The rest of the lake/sea will be declared open water, though how it will be used has yet to be agreed (Caspian Summit, 2014). This agreement applied some principles of international maritime law concerning the exclusive national sovereignty over
2005). Turkmenistan te prije svega Iran odbijali su prijedlog Kazahstana i Rusije o razgraničenju dna jezera na temelju načela medijanskih linija, koje bi Kazahstanu dalo 29 \%, Azerbajdžanu 20 \%, Rusiji 16 \%, Turkmenistanu $21 \%$ i Iranu $14 \%$ udjela (Winstone i Young, 2005, 11) jer su obje države željele veći udio.

Bilateralni sporazumi koje su potpisivali Rusija, Kazahstan i Azerbajdžan od 1998. do 2001. odnosili su se na dno jezera, ali ne i na površinu. Rusija je počela zastupati stav da bi dio jezera trebao biti pod zajedničkom kontrolom svih pet država (Zonn, 2005, 250). Demarkacija površine jezera odvila bi se na temelju formiranja ,„,nacionalnih” ili „obalnih”zona koje se prostiru od određene obale" (Winstone i Young, 2005, 11). No glavna prepreka u multilateralnom sporazumu bio je opseg nacionalnih zona. Rusija je zastupala stav da bi nacionalne zone trebale biti 15 nm, dok su se Azerbajdžan, Kazahstan i Turkmenistan zalagali za $40 \mathrm{~nm}$ (Winstone i Young, 2005, 11). Kazahstan i Turkmenistan preferiraju veći opseg nacionalnih zona kako bi došli do većeg pristupa prirodnim resursima ili mogućnosti bušenja naftnih izvora na dnu jezera, što ih dovodi u sukob s Rusijom, koja nastoji kontrolirati što veće "zajedničko područje” jezera. Iran se zalagao za zajedničko upravljanje jezerom ili barem za jednaki udio nad jezerom svih priobalnih država (Bahman, 2004). Ujedno se suprotstavlja definiranju jezera kao mora jer bi to, između ostaloga, omogućilo ulazak i američkoj ratnoj mornarici (Zimnitskaya i Geldern, 2011, 6). Sa susjednim Azerbajdžanom usto se spori oko naftnog polja Alborz/Alove, kao što se i Turkmenistan spori s Azerbajdžanom oko nekih drugih naftnih polja (Bahman, 2004).

Značajan napredak u definiranju statusa postignut je tek na Četvrtome kaspijskom samitu održanom 2014. u Astrahanu. Na njemu su se priobalne države dogovorile o uspostavi nacionalnog suvereniteta u pojasu od $15 \mathrm{~nm}$ od obale te isključivoga korištenja vode i vodnog bogatstva u narednih 10 nm (Caspian Summit, 2014). Ostatak jezera/mora bit će proglašen otvorenim vodama, o čijem se korištenju tek treba dogovoriti (Caspian Summit, 2014). Tim sporazumom primijenjena su neka načela međunarodnoga pomorskog prava koja se tiču isključivoga nacionalnog suvereniteta
D. Boban

K. Lončar

Geopolitical

Consequences of Resolving the

Legal Status of

the Caspian Sea:

Security and Energy Aspects

Geopolitičke posljedice rješavanja pravnog statusa Kaspijskog jezera: sigurnosni i energetski aspekti 
HRVATSKI

GEOGRAFSKI

GLASNIK

78/2,77-100 (2016.)

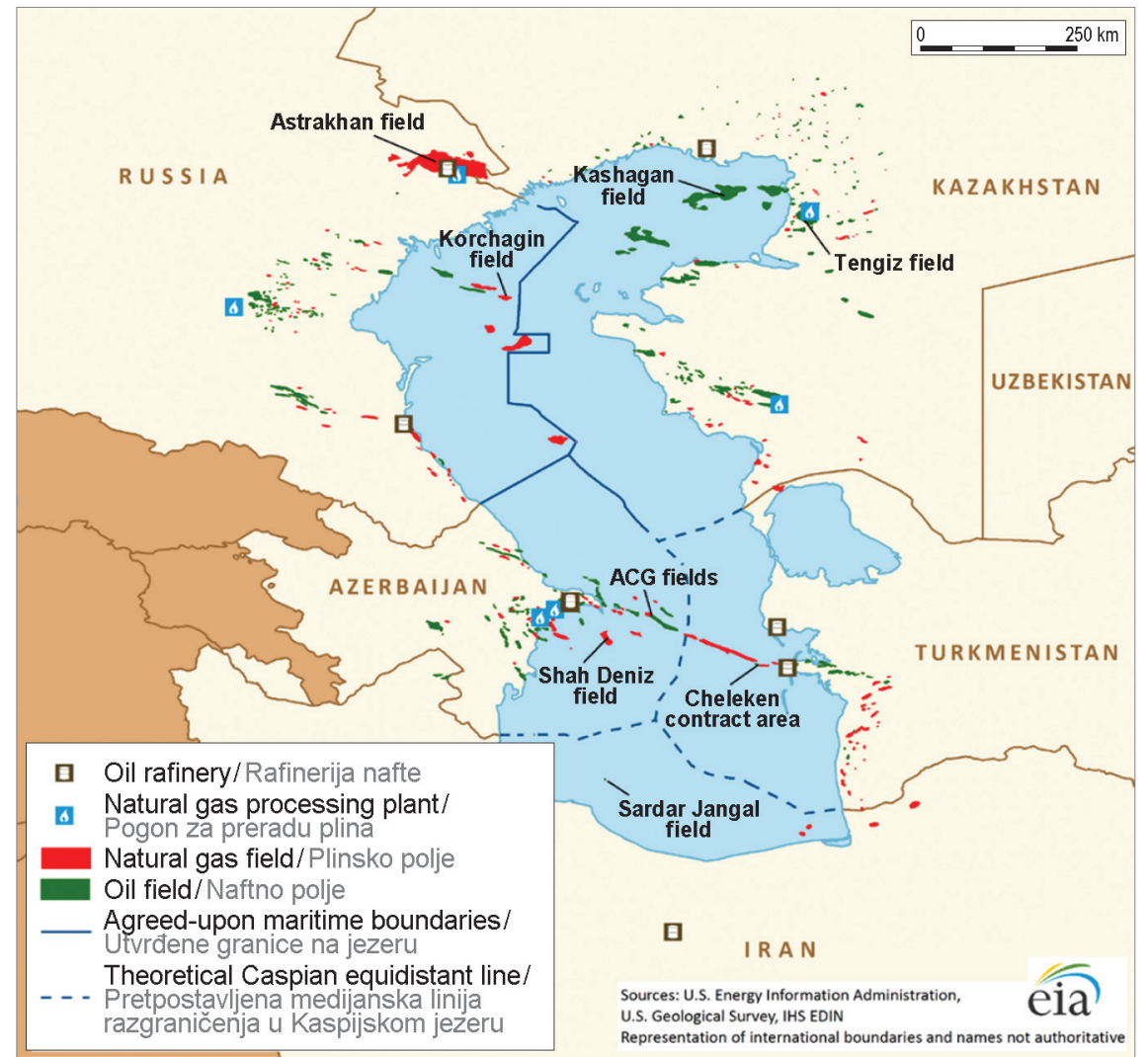

Fig. 1 Agreed-upon maritime boundaries, theoretical Caspian equidistant lines, and natural gas and oil fields in the Caspian region

SI. 1. Utvrđene i neutvrđene granice na Kaspijskom jezeru te plinska i naftna polja

Source / Izvor: Overview of oil and natural gas in the Caspian Sea region, 2015

a part of the water. Although it is not entirely in accordance with the Russian stance on the division and control of the Sea, Russia did not come out as a loser. President Putin emphasized that, in addition to the legal and economic importance of the agreement, it has vital security importance because it ensures that only the Caspian states have the right to operate military forces in the region (Press statement, 2015). This agreement shows that the Caspian countries have become more willing to compromise than before, and some of them have reached agreements on delimitation that were previously not possible (Fig. 1). By 2015, the greatest progress was achieved by Kazakhstan, which signed an agreement on delimitation of the Sea's bottom, first with Turkmenistan (Kazakhstan's parliament, 2015) and then with Russia (Russia, Kazakhstan, 2015), while Azerbaijan, Iran and Turkmenistan have yet to reach agreements (Differences, 2015). By the summer of 2016, the final convention on the legal status of the Sea had still not been signed - it nad dijelom voda. Premda to nije posve u skladu s ruskim stavom o podjeli i kontroli jezera, Rusija iz toga ipak nije izašla kao gubitnica. Predsjednik Putin naglasio je da osim pravne i ekonomske važnosti sporazum ima i sigurnosnu važnost jer je njime određeno da će samo kaspijske države imati pravo na vojne snage u regiji (Press statement, 2015). Taj dogovor pokazuje da su kaspijske zemlje postale spremnije na kompromis nego prije te su neke od njih postigle dogovore o razgraničenju koji dotad nisu bili mogući (sl.1). Do 2015. najveći napredak postigao je Kazahstan, koji je prvo s Turkmenistanom (Kazakhstan's parliament, 2015), a potom s Rusijom potpisao sporazum o razgraničenju na jezerskom dnu (Russia, Kazakhstan, 2015), dok Azerbajdžan, Iran i Turkmenistan još uvijek ne uspijevaju postići dogovor o tome (Differences, 2015). Do ljeta 2016. još uvijek nije potpisana završna konvencija o pravnom statusu jezera te je to ostavljeno za sastanak predviđen u 2017. 
was postponed for a meeting scheduled for 2017.

The Astrakhan agreement shows that the Russian position on the division of the Caspian Sea primarily relates to the seabed, rather than the surface water (Differences, 2015). The aim of the division of the seabed is of an economic nature, and leaving part of the water under the joint control has both security and political goals. At the same time, signing the agreement on the Caspian Sea has allowed Russia to redirect its attention from the region to the "far abroad". In this case, instead of engaging its military forces to secure itself against Caspian neighbors, it can redirect them for use in the Middle East. Resolving this major regional problem has allowed Russia to strengthen its global impact, which is shown in the next section.

\section{The militarization of the Caspian region and the Russian geopolitical dash to the south}

Although there are disagreements about the use and demarcation of the Caspian Sea, the states that share it are not in conflict and do not have poor relations. The nearest conflicts are in the central and western Caucasus, and even Russia and Azerbaijan enjoy relatively good relations, despite the fact that Russia is an ally of Armenia. The framework agreement on the final status of the Caspian Sea of 2014 therefore enabled the risk of conflict between coastal states to be reduced, despite the fact that their respective fleets had been strengthened in recent years.

The militarization of the Caspian region is one of the most dangerous factors of instability in this part of the world, which, due to its complexity and potential for damage, could easily spread to neighboring regions. Garibov $(2014,41)$ argues that the main reason for the militarization of the Caspian Sea is connected with the "discovery of the significant hydrocarbon resources in the sea after the collapse of the Soviet Union and location of substantial portion of them often in the areas claimed by the several coastal states, as well as absence of the agreement on legal status of the Caspian created fertile grounds for naval competition in the sea". Militarization, therefore, arises due to the efforts of countries of the region to protect their oil and gas sources from foreign interests, terrorist attacks, or even
Astrahanski dogovor pokazuje da se ruski stav o podjeli Kaspijskog jezera prije svega odnosi na morsko dno, a tek potom na vodenu površinu (Differences, 2015) jer je cilj podjele dna jezera ekonomske naravi, a stavljanje dijela vodene površine pod zajedničku kontrolu ima sigurnosne i političke ciljeve. Sklapanje sporazuma o Kaspijskom jezeru istodobno omogućuje Rusiji da svoju pozornost preusmjeri s regije prema „daljem susjedstvu”. U tom slučaju, umjesto da angažira svoje vojne snage kako bi se osigurala od svojih kaspijskih susjeda, ona ih preusmjerava i upotrebljava za vojne akcije na Bliskom istoku. Time je rješavanje jednoga regionalnog problema omogućilo Rusiji da ojača svoj globalni utjecaj, kako će biti opisano u sljedećem poglavlju.

\section{Militarizacija kaspijske regije i ruski geopolitički skok na jug}

Premda postoje neslaganja u vezi s načinom korištenja Kaspijskog jezera i razgraničenjem na njemu, države koje ga dijele nisu u ratnom sukobu i nemaju ozbiljno narušene međusobne odnose. Najbliži sukobi vodili su se na srednjem i zapadnom Kavkazu, ali su čak i Rusija i Azerbajdžan u relativno dobrim odnosima, iako je Rusija saveznica Armenije. Postignuti okvirni sporazum o konačnom statusu Kaspijskog jezera iz 2014. stoga omogućuje smanjenje opasnosti od sukoba između priobalnih država, iako su one tijekom proteklih godina već ojačale svoje flote.

Militarizacija kaspijske regije jedan je od najopasnijih čimbenika nestabilnosti u tom dijelu svijeta, koji se zbog svoje složenosti i potencijalne štete lako može proširiti i na okolne regije. Garibov ističe da je glavni razlog militarizacije u Kaspijskom jezeru povezan uz „pronalazak velikih količina ugljikovodika u jezeru nakon raspada SSSR-a, gdje se značajna količina tih resursa nalazi na područjima neriješenog statusa između država regije, te uz nedostatak sporazuma o pravnom statusu jezera dolazi do pomorskog nadmetanja priobalnih država" (Garibov, 2014, 41). Militarizacija se dakle javlja zbog nastojanja država regije da zaštite svoje izvore nafte i plina od stranih interesa, terorističkih napada ili čak nasilnih pokušaja kontrole od drugih pomorski snažnijih kaspijskih zemalja koje nastoje nametnuti
D. Boban

K. Lončar

Geopolitical

Consequences of Resolving the

Legal Status of

the Caspian Sea:

Security and Energy Aspects

Geopolitičke

posljedice rješavanja pravnog statusa Kaspijskog jezera: sigurnosni i energetski aspekti 
violent attempts at control from other Caspian countries with stronger navies, seeking to impose their own control over these rich resources. Central Asian countries, such as Kazakhstan and Turkmenistan, especially after the economic upturn "due to the increased energy revenues during 2000s" (Garibov, 2014, 41), saw the need to arm their fleets to avoid becoming totally dependent on Russia, as the strongest military force in region. However, due to Central Asia's instability and authoritarian regimes, any provocation or unintentional military conflict over particular resources or areas in the Caspian Sea could potentially lead to extensive military conflict.

Some countries, like Iran and Azerbaijan, proposed "that the whole Caspian Sea be completely demilitarised. Russia has rejected the idea" (Winstone and Young, 2005, 23). ${ }^{4}$ Also, Russia's rejection on demilitarizing the Caspian Sea was supported by the US "which has been trying to maximise its influence in the region since the early 1990s" (Winstone and Young, 2005, 23). ${ }^{5}$ The US clearly saw military and security cooperation with littoral states as a way of entering the region, something that was opposed by Russia who "clearly sees itself - not the USA - as bearing the security burden." (Winstone and Young, 2005, 23). ${ }^{6}$ However, most countries recognized the danger of over-arming, and in the mid-2000s two initiatives emerged that sought to limit the problem and coordinate fleets of Caspian states. The first initiative was led by the US and the second by Russia, but both eventually ended in failure. The US initiative "Caspian Guard" was conceived as "an integrated counter proliferation, counterterrorism, and illegal trafficking effort to help secure the Caspian Basin from transnational threat" (Garibov, 2014, 48). ${ }^{7}$ The initiative was set up in 2003 , and actually conceived primarily as a plat- vlastitu kontrolu nad tim bogatim izvorima. Države Srednje Azije, kao što su Kazahstan i Turkmenistan, posebice nakon gospodarskog uzleta „uzrokovanog povećanim prihodima od energenata" (Garibov, 2014, 41), uvidjele su potrebu naoružavanja svojih jezerskih flota kako ne bi postale potpuno ovisne o Rusiji kao najsnažnijoj vojnoj sili u regiji. No kako je Srednja Azija nestabilna i u njoj vladaju autoritarni režimi, svaka mala provokacija ili nenamjerni vojni sukob oko pojedinih resursa ili područja u Kaspijskom jezeru mogli bi dovesti do opsežnoga vojnog sukoba.

Neke zemlje, npr. Iran i Azerbajdžan, predložile su „da cijelo Kaspijsko jezero bude potpuno demilitarizirano. Rusija je odbila tu ideju" (Winstone and Young, 2005, 23). ${ }^{4}$ Usto, odbijanje Rusije da se Kaspijsko jezero demilitarizira podupro je SAD, „koji je pokušavao maksimizirati svoj utjecaj u regiji od ranih devedesetih godina 20. stoljeća" (Winstone and Young, 2005, 23). ${ }^{5}$ SAD je jasno vidio vojnu i sigurnosnu suradnju s priobalnim državama kao način ulaska u regiju, nešto čemu se odupirala Rusija, koja „jasno vidi sebe - a ne SAD - kao nositeljicu tereta sigurnosti" (Winstone and Young, 2005, 23). ${ }^{6}$ Ipak, većina država uvidjela je opasnost od prekomjernog naoružavanja te su se sredinom prvoga desetljeća 21. stoljeća pojavile dvije inicijative koje su nastojale ograničiti taj problem $\mathrm{i}$ koordinirati jezerske flote kaspijskih država. Prva inicijativa bila je predvođena SAD-om, a druga Rusijom, ali su obje završile neuspjehom. Američka inicijativa „Kaspijska garda” bila je zamišljena kao ,integrirana protuproliferacijska, protuteroristička, protukrijumčarska inicijativa usmjerena na osiguranje Kaspijskog jezera od transnacionalnih prijetnji" (Garibov, 2014, 48). ${ }^{7}$ Inicijativa je dana 2003. i zapravo zamišljena ponajviše

\footnotetext{
4 Winstone and Young refers to: Donaldson, J. W., 2004: Bilateral Agreements Raise Stakes in Caspian Competition, Jane's Intelligence Review 16 (5), $48-53$. 4 Winstone i Young referiraju se na: Donaldson, J.W., 2004: Bilateral Agreements Raise Stakes in Caspian Competition, Jane’s Intelligence Revierw 16 (5), 48-53. 5 Ibid

5 Ibid

6 Ibid

6 Ibid

7 Garibov referes to: "J.L. Jones, "U.S. European Command Posture", Statement of General James L. Jones Commander, U.S. European Command U.S. Marine Corps, Senate Armed Services Committee, 7 March 2006, pp. 16-17, in G.J. Dyekman, Security Cooperation: A key to the challenges of the 21st century, Strategic Studies Institute of the US Army War College, November 2007, available at: http://www.strategicstudiesinstitute.army.mil/pdffiles/ pub820.pdf (last retrieved 19 February 2014).”

7 Garibov se referira na: „J.L. Jones, „U.S. European Command Posture”, Statement of General James L. Jones Commander, U.S. European Command U.S. Marine Corps, Senate Armed Services Committee, 7 March 2006, pp. 16-17, in G.J. Dyekman, Security Cooperation: A key to the challenges of the 21st century, Strategic Studies Institute of the US Army War College, November 2007, available at: http://www.strategicstudiesinstitute.army.mil/pdffiles/
} pub820.pdf (last retrieved 19 February 2014).” 
form for increasing the presence of the US in Central Asia and to access the natural resources of the region with the aim of diversifying their sources of energy at a time when the situation in the Middle East was chaotic. The US initiative envisaged the creation of an integrated airspace, and maritime and air control systems for Kazakhstan and Azerbaijan (Garibov, 2014, 48). This was contrary to Russia's geopolitical interests in the region and due to the influence of Russia over Turkmenistan and Kazakhstan, and the initiative never really took off.

In response to the American attempt of "infiltration", in June 2005 Russia began its own initiative CASFOR, referring to the creation of the Caspian naval group for operational cooperation (Garibov, 2014) ${ }^{8}$. With this initiative, Russia emphasized the view that only Caspian countries could participate in joint planning to establish security on the Sea, and it considered any interference with said security, by nations not located the shores of the Caspian Sea, unacceptable (Socor, 2005). The Russian initiative was exclusively directed against the interference of the US in the area of Central Asia and the Caspian Sea, in which Russia gained support from Iran - which is also wary of a US entry into the region. At the same time, Russia sought to strengthen its dominant position on the Sea through this initiative. However, the problem of the initiative was that it did not receive the support of Kazakhstan, Turkmenistan and Azerbaijan, since none of these countries wanted to be dependent on the maritime domination of Russia, which would be the main beneficiary of the newly acquired influence and use it to secure control over the disputed sources of natural gas and oil in the region (Garibov, 2014). After the failure of this initiative, all Caspian countries continued with their further arming (Tab. 1). Azerbaijan, Kazakhstan and Turkmenistan are doing so out of fear of the influence that Russia's Caspian navy has on the energy policy of their countries (Kucera, 2012), which is exacerbated by the fact that Russia is ahead of them in terms of arms. Laruelle and Peyrouse $(2009,23)$ point out that "the Russian fleet is the most powerful of the Caspian and includes around one hundred ships with multiple dimensions and func- kao platforma za sve veću prisutnost SAD-a na području Srednje Azije, kako bi osigurao prirodne resurse regije s ciljem vlastite diversifikacije izvora energenata u doba kad je stanje na Bliskom istoku bilo kaotično. Američka inicijativa predvidjela je stvaranje integriranoga zračnog prostora, pomorske i zračne sustave kontrola za Kazahstan i Azerbajdžan (Garibov, 2014, 48). To je bilo protiv ruskih geopolitičkih interesa u regiji te zbog utjecaja $\mathrm{Ru}-$ sije nad Turkmenistanom i Kazahstanom inicijativa nije nikada uistinu zaživjela.

Kao odgovor na američki pokušaj „infiltracije”, u lipnju 2005. Rusija je započela vlastitu inicijativu CASFOR, što se odnosilo na stvaranje Kaspijske pomorske skupine za operacijsku suradnju (Garibov, 2014). ${ }^{8}$ Rusija je svojom inicijativom naglašavala stav da samo kaspijske zemlje mogu sudjelovati u zajedničkim planovima uspostave sigurnosti na jezeru, gdje se smatra neprihvatljivim bilo kakvo upletanje država koje nisu na njegovim obalama u sigurnost jezera (Socor, 2005). Ruska inicijativa bila je isključivo usmjerena protiv upletanja $\mathrm{SAD}-\mathrm{a} \mathrm{u}$ područje Srednje Azije i Kaspijskog jezera, u čemu je zadobila podršku Irana, koji se također bojao američkog ulaska u regiju. Ujedno je Rusija tom inicijativom nastojala učvrstiti svoj dominantni položaj na jezeru. No problem inicijative bio je taj što nije zadobio podršku Kazahstana, Turkmenistana i Azerbajdžana, jer nijedna od tih država nije htjela biti ovisna o pomorskoj dominaciji Rusije, koja bi se ponajviše koristila novostečenim utjecajem za osiguranje kontrole nad spornim izvorima prirodnog plina i nafte u regiji (Garibov, 2014). Neuspjehom $\mathrm{i}$ ove inicijative sve su kaspijske države nastavile s naoružavanjem (tab. 1). Azerbajdžan, Kazahstan i Turkmenistan čine to zbog straha da Rusiji njezina kaspijska mornarica omogućuje da utječe na energetsku politiku tih zemalja (Kucera, 2012), a dodatni poticaj tome strahu jest $\mathrm{i}$ to što ona prednjači u jačanju svojih snaga. Laruelle i Peyrouse ističu da „ruska flota na Kaspijskom jezeru uključuje oko sto brodova raznih dimenzija i funkcija, kao što su brodovi za patrolu, brodovi za zračno nadgledava-
Geopolitical

Consequences of Resolving the

Legal Status of

the Caspian Sea:

Security and Energy Aspects

Geopolitičke posljedice rješavanja pravnog statusa Kaspijskog jezera: sigurnosni i energetski aspekti

8 Garibov refers to: "Ministry of Defense of the Russian federation, Caspian Flotilla, http://eng.mil.ru/en/structure/forces/navy/associations/structure/ forces/type/navy/kasp/history.htm (last retrieved 21 February 2014)."

8 Garibov se referira na: „Ministry of Defense of the Russian federation, Caspian Flotilla, http://eng.mil.ru/en/structure/forces/navy/associations/structure/forces/type/navy/kasp/history.htm (last retrieved 21 February 2014)." 
GEOGRAFSKI

GLASNIK

78/2,77-100 (2016.) tions: patrol boats, minesweepers, hovercrafts, aerial observation ships, different classes of combat boats, attack boats and missile launchers." This is a continuation of the modernization that was cut short by the disintegration of the USSR; in May 2011, the commander of the Russian Navy Admiral Vysotsky said that by 2020, the Caspian fleet would get at least 16 new ships (Aryan, 2011). Russia has also been strengthening its air force and training coastal missile units (Kucera, 2012).

In addition to the aforementioned incentives, the increase in the importance of the Sea on a global scale is of paramount consideration. In October 2015, Russia began airstrikes in Syria, which, on October $7^{\text {th }}$, were complemented with missile attacks from the military ships on the Caspian Sea. Since Turkey does not allow Russia to fire missiles over its territory, and Iran is nje, razarači, borbeni brodovi, napadački brodovi i mnogi drugi" (Laruelle i Peyrouse, 2009, 23). Time se nastavlja modernizacija koja je drastično zaustavljena raspadom SSSR-a; u svibnju 2011. zapovjednik ruske mornarice admiral Vysotsky izjavio je da će do 2020. Kaspijska flota dobiti najmanje šesnaest novih brodova (Aryan, 2011). Rusija usto jača i svoje zračne snage te stvara obalne raketne postrojbe (Kucera, 2012).

Dodatni poticaj takvu jačanju jest spomenuti porast važnosti jezera u globalnim razmjerima. U listopadu 2015. Rusija je započela zračne udare u Siriji, koje je 7. listopada nadopunila raketnim napadima s vojnih brodova na Kaspijskom jezeru. Budući da Turska ne dozvoljava prelet ruskih raketa preko svojeg teritorija, a Iran je ruski saveznik u toj akciji,

Tab. 1 The naval forces of the Caspian littoral states: military personnel and major vessels (above 250 tonnes of FLD* level)

\begin{tabular}{|c|c|c|c|c|c|}
\hline & Azerbaijan & $\operatorname{Iran}^{* *}$ & Kazakhstan & Russia & Turkmenistan \\
\hline Active personnel & 2200 & 3000 & 3000 & 15000 & 500 \\
\hline $\begin{array}{l}\text { Principal surface } \\
\text { combatants } \\
\text { (FLD }>1500 \text { tonnes) }\end{array}$ & & & & $\begin{array}{l}2 \text { Frigates } \\
\text { (Gepard class) }\end{array}$ & \\
\hline $\begin{array}{l}\text { Patrol and coastal } \\
\text { combatants } \\
\text { (FLD between } \\
250-1500 \text { tonnes) }\end{array}$ & $\begin{array}{l}1 \text { Corvette } \\
\text { (Petya II class) } \\
1 \text { Offshore patrol } \\
\text { vessel } \\
3 \text { Coastal patrol } \\
\text { crafts w/anti-ship } \\
\text { missiles } \\
3 \text { Patrol boats }\end{array}$ & $\begin{array}{l}1 \text { Corvette } \\
\text { (Mowj class) } \\
3 \text { Coastal patrol } \\
\text { crafts w/anti ship } \\
\text { missiles } \\
\text { Other smaller } \\
\text { missile and artillery } \\
\text { boats }\end{array}$ & $\begin{array}{l}1 \text { Coastal patrol } \\
\text { craft w/guided } \\
\text { missiles } \\
5 \text { Fast patrol boats } \\
15 \text { Patrol boats }\end{array}$ & $\begin{array}{l}2 \text { Patrol crafts } \\
\text { w/guided missiles } \\
3 \text { Patrol hydrofoils } \\
\text { with missiles } \\
1 \text { Patrol craft with } \\
\text { CIWS or SAM*** }\end{array}$ & $\begin{array}{l}2 \text { Fast patrol crafts } \\
\text { w/guided missiles } \\
4 \text { Coastal patrol } \\
\text { crafts w/anti-ship } \\
\text { missiles } \\
12 \text { Fast patrol boats } \\
1 \text { Patrol boat }\end{array}$ \\
\hline $\begin{array}{l}\text { Mine warfare and } \\
\text { countermeasure } \\
\text { vessels }\end{array}$ & $\begin{array}{l}4 \text { Coastal mine } \\
\text { hunters }\end{array}$ & $\begin{array}{l}1 \text { Coastal mine } \\
\text { sweeper } \\
\text { A number } \\
\text { of other ships }\end{array}$ & & $\begin{array}{l}5 \text { Coastal mine } \\
\text { sweepers } \\
2 \text { Inshore mine } \\
\text { hunters }\end{array}$ & \\
\hline Amphibious & $\begin{array}{l}3 \text { Landing ships } \\
\text { medium } \\
2 \text { Medium landing } \\
\text { crafts } \\
1 \text { Landing craft } \\
\text { utility }\end{array}$ & & & $\begin{array}{l}2 \text { Medium landing } \\
\text { crafts } \\
4 \text { Landing crafts } \\
\text { utility } \\
5 \text { Landing crafts } \\
\text { air-cushion } \\
\text { (hovercraft) }\end{array}$ & \\
\hline
\end{tabular}

Source: The International Institute for Strategic Studies, The Military Balance 2014, Routledge, London, February 2014; Garibov, $2014,56$.

* FLD - full-load displacement;

**It is reported in several sources that Iran possess about 100 small missile and patrol boats in the Caspian Sea. However, many of them either fall below the $250 \mathrm{FLD}$ limit or there is not available information on the exact dislocation of Iranian naval ships (either in the Gulf or in the Caspian Sea). Therefore, the table includes only confirmed information about Iran's naval capability in the Caspian Sea:

${ }^{*} *$ CIWS - a close-in weapon system (fast-reaction, rapid-fire gun system providing a vessel with a terminal defense against anti-ship missiles that have penetrated other defenses); SAM - surface-to-air missile 
Tab. 1. Pomorske snage obalnih država: vojno osoblje i važna plovila (iznad 250 tona ukupne težine broda - FLD*)

\begin{tabular}{|c|c|c|c|c|c|}
\hline & Azerbajdžan & $\operatorname{Iran} * *$ & Kazahstan & Rusija & Turkmenistan \\
\hline Aktivno osoblje & 2200 & 3000 & 3000 & 15000 & 500 \\
\hline $\begin{array}{l}\text { Glavna površinska } \\
\text { borbena plovila } \\
\text { (FLD }>1500 \text { tona) }\end{array}$ & & & & $\begin{array}{l}2 \text { fregate } \\
\text { (klasa Gepard) }\end{array}$ & \\
\hline $\begin{array}{l}\text { Obalni i patrolni } \\
\text { brodovi } \\
\text { (FLD 250- } \\
1500 \text { tona) }\end{array}$ & $\begin{array}{l}1 \text { korveta } \\
\text { (klasa Petya II) } \\
1 \text { ophodno plovilo } \\
3 \text { obalna patrolna } \\
\text { plovila s protu- } \\
\text { brodskim } \\
\text { projektilima } \\
3 \text { patrolna čamca }\end{array}$ & $\begin{array}{l}1 \text { korveta } \\
\text { (klasa Mowj) } \\
3 \text { priobalna } \\
\text { patrolna plovila s } \\
\text { protu-brodskim } \\
\text { projektilima }\end{array}$ & $\begin{array}{l}1 \text { obalno plovilo } \\
\text { s projektilima } \\
5 \text { brzih patrolnih } \\
\text { čamaca } \\
15 \text { patrolnih } \\
\text { čamaca }\end{array}$ & $\begin{array}{l}2 \text { patrolna plovila } \\
\text { s projektilima } \\
3 \text { patrolna } \\
\text { hidrokrilca s } \\
\text { projektilima } \\
1 \text { patrolno plovilo } \\
\text { s CIWS i SAM } \\
\text { sustavom*** }\end{array}$ & $\begin{array}{l}2 \text { brza plovila za } \\
\text { patrolu s projektilima } \\
4 \text { obalna plovila za } \\
\text { patrolu s protu-brod. } \\
\text { projektilima } \\
12 \text { brzih patrolnih } \\
\text { čamaca } \\
1 \text { patrolni čamac }\end{array}$ \\
\hline $\begin{array}{l}\text { Plovila za rat } \\
\text { s minama i } \\
\text { protumjere }\end{array}$ & $\begin{array}{l}4 \text { obalna } \\
\text { tragača mina }\end{array}$ & $\begin{array}{l}1 \text { obalni } \\
\text { minolovac } \\
\text { Brojni } \\
\text { drugi brodovi }\end{array}$ & & $\begin{array}{l}5 \text { obalnih } \\
\text { minolovaca } \\
2 \text { priobalna tragača } \\
\text { mina }\end{array}$ & \\
\hline Amfibije & $\begin{array}{l}3 \text { srednja desantna } \\
\text { broda } \\
2 \text { srednja desantna } \\
\text { plovila } \\
1 \text { desantni čamac }\end{array}$ & & & $\begin{array}{l}2 \text { srednja desantna } \\
\text { plovila } \\
4 \text { desantna čamca } \\
5 \text { desantnih } \\
\text { zračnih plovila } \\
\text { (hovercrafts) }\end{array}$ & \\
\hline
\end{tabular}

Izvor: The International Institute for Strategic Studies, The Military Balance 2014, Routledge, London, February 2014; Garibov, $2014,56$.

*FLD - puni deplasman broda;

**U nekoliko je izvora objavljeno da Iran posjeduje oko 100 raketnih i patrolnih čamaca u Kaspijskom moru. Međutim, mnogi od njih su ili ispod granice od 250 FLD-a ili nije dostupan podatak o točnom smještaju iranskih ratnih brodova (bilo u Perzijskom zaljevu ili u Kaspijskom moru). Dakle, tablica uključuje samo potvrđena informacije o iranskim pomorskim snagama u Kaspijskom moru;

***CIWS - sustav oružje blizu-u (sustav brzo-reakcije, brze paljbe pruža plovilu posljednju obranu od protubrodskih projektila koji su probili druge obrane); SAM - projektili površina-zrak.

Russia's ally in the area, the Sea has become the most convenient location for Russian strikes via Iran. The agreement between Caspian states from 2014, which defines the territorial waters and the common waters that belong to all coastal states, has been a better solution for Russia than the other option - completely splitting the Sea into five national zones. Although Russia would receive more territorial waters than it has now with such an agreement, a common body of water enables it to station its warships further south, and thus to fire missiles that fly over the common area of the Sea and Iran.

In August 2016 it was announced that Russia would have its own air base in Iran from which it would launch military missions in Syria. The military alliance between these two countries, that have been isolated from the
Geopolitical

Consequences of Resolving the

Legal Status of

the Caspian Sea:

Security and Energy Aspects

Geopolitičke posljedice rješavanja pravnog statusa Kaspijskog jezera: sigurnosni i energetski aspekti jezero je postalo najbliža baza za ruske udare preko teritorija te zemlje. Sporazum između kaspijskih država iz 2014. kojim se utvrđuju teritorijalne vode i zajedničke vode koje pripadaju svim priobalnim državama postaje tako za Rusiju bolje rješenje nego ono kojim bi se jezero potpuno podijelilo u pet nacionalnih zona. Premda bi Rusija tim rješenjem dobila više teritorijalnih voda nego što ih dobiva sada, zajednička vodena površina omogućuje joj da svoje ratne brodove stacionira južnije te da s njih ispaljuje projektile koji prelijeću preko zajedničke površine jezera i Irana.

U kolovozu 2016. objavljeno je da će Rusija imati svoju zračnu bazu u Iranu s koje će slati svoje ratno zrakoplovstvo u vojne misije u Siriji. To vojno savezništvo dviju zemalja izoliranih od 
West, has enabled Russia's geopolitical "dash to the south"; not exactly the kind advocated by Vladimir Zhirinovsky, but one that allows the country to get to an aforementioned "warm sea" and to play an active role in political and military operations in the Middle East. Russian authorities have also reached a primary foreign policy goal that was never even achieved by the USSR to become an important player in this part of the world. The Agreement of Astrakhan increased the geopolitical power of Russia, which, combined with the annexation of the Crimea and the control of the port in Sevastopol, meaningfully extends its military presence to the south.

\section{Control of oil and gas fields and transportation routes in the Caspian region}

The Caspian region has great military and security significance, but many countries and multinational corporations have their own interests in the region as well. These are primarily related to the exploitation of oil and gas, and the sale thereof on the world market. However, for these goals to become realized, adequate infrastructure is a precondition. The role of multinational corporations and the political involvement of world powers, whose money enables the construction of infrastructure, are extremely important factors. This is most evident in the case of Azerbaijan, most of whose oil has been exported through the Baku-Tbilisi-Ceyhan Pipeline (BTC) which was built mostly with the foreign capital.

Russia has the world's greatest gas reserves (Bilgin, 2009, 4483), but has insufficiently-developed infrastructure for its production (Marketos, 2009, 2). In addition, it does not have significant sources of gas in its sector of the (Caspian) Sea (Bahgat, 2002,274), and is a special actor in regional energy policy due to its role as the main organizer of gas transportation for neighboring producers. Western countries and China are particularly interested in the production of gas, and tend to bring gas to themselves. Therefore, we can divide actors in the region into three groups with regard to their role in the trade and production of oil and gas: exporters (Kazakhstan, Azerbaijan and Turkmenistan); importers (Western countries and China); and transport countries (Russia, and, to some degree Iran). Iran imports gas from Turkmenistan because
Zapada omogućilo je Rusiji geopolitički „skok na jug", ne onakav za kakav se zalagao Vladimir $\check{Z}_{\mathbf{i}}$ rinovski, ali ipak takav koji omogućuje toj zemlji da dopre do toplih mora i da igra aktivnu ulogu u političkim i vojnim operacijama na Bliskom istoku. Ruske vlasti tako su postigle prvi vanjskopolitički cilj koji nije uspio postići ni SSSR, a to je da budu važan akter u tom dijelu svijeta. Sporazum iz Astrahana povećao je geopolitičku moć Rusije, koja, u kombinaciji s aneksijom Krima i kontrolom luke u Sevastopolju, pomiče svoju vojnu prisutnost prema jugu.

\section{Kontrola nad naftnim i plinskim poljima i transportnim pravcima u kaspijskoj regiji}

Kaspijska regija ima veliku vojnu i sigurnosnu važnost, ali mnoge države i multinacionalne korporacije imaju i druge interese. To se prije svega odnosi na iskorištavanje nafte i plina i njihovo plasiranje na svjetska tržišta. No kako bi se nafta i plin uopće mogli iskorištavati i plasirati na svjetska tržišta, potrebna je adekvatna infrastruktura. Za njezinu izgradnju iznimno je važna uloga multinacionalnih korporacija i političkog angažmana svjetskih sila, bez čijeg novca to ne bi bilo moguće. To je ponajviše vidljivo u slučaju Azerbajdžana, koji najviše nafte izvozi kroz naftovod Baku - Tbili - Ceyhan (BTC), izgrađen uglavnom stranim kapitalom.

Rusija obiluje plinskim rezervama, koje su najveće na svijetu (Bilgin, 2009, 4483), ali ima nezadovoljavajuće razvijenu infrastrukturu za proizvodnju plina (Marketos, 2009, 2). Usto, ona nema značajne izvore plina u svojem sektoru jezera (Bahgat, 2002, 274) te je posebni akter u regionalnoj energetskoj politici kao glavni organizator transporta tog energenta za potrebe susjednih proizvođača. Za njihovu proizvodnju naročito su zainteresirane zapadne zemlje i Kina, koje taj plin nastoje dovesti do svojeg teritorija. Zbog toga možemo aktere u toj regiji podijeliti u tri skupine s obzirom na njihovu ulogu u trgovini naftom i plinom i njihovoj proizvodnji: izvoznike (Kazahstan, Azerbajdžan i Turkmenistan), uvoznike (zapadne zemlje i Kina) te transportne zemlje, a to su Rusija i uvjetno Iran. Ta zemlja uvozi plin 
of the gas consumption demands in the north of the country. Although it is already a major world exporter of gas, produced from its own resources in other parts of its territory, Iran is still expected to develop its own routes to transport Caspian energy to world markets.

The struggle over entering into the production and trade of oil and gas in the Caspian region began immediately after the collapse of the USSR. In 1995, at the summit of Turkic states, Turkish President Suleyman Demirel stressed the desire of his country to build gas and oil pipelines from Azerbaijan, Kazakhstan and Turkmenistan across Turkish territory in order to reduce the dependence of Caspian countries on Russia (Bolukbasi, 1998, 397). This was not only about Turkish financial interests, i.e. transport profits, but also about political influence which could be achieved over these countries by such an arrangement. Old oil and gas pipelines from the Soviet era pass over Russia to the West, while there have been new attempts to build new ones toward China and Iran and even through Afghanistan to India and Pakistan (Rashid, 2001) (Fig. 2 and Fig. 3). These developments threaten the influence of Russia, particularly when other participants are involved in this (US, China, Great Britain) are trying to divert the transport of gas and oil to their own markets, and encourage the Caspian states to exploit their own oil and gas resources (Baryls- iz Turkmenistana zbog svojih potreba na sjeveru zemlje premda je značajni svjetski izvoznik plina proizvedenog iz vlastitih izvora na drugim dijelovima svojeg teritorija i tek se očekuje da će razviti svoje pravce za transport kaspijskih energenata na svjetska tržišta.

Borba oko ulaska u proizvodnju i trgovinu naftom i plinom u kaspijskoj regiji počela je odmah nakon raspada SSSR-a. Turski predsjednik Suleyman Demirel još je 1995. na samitu turkijskih država naglasio želju svoje zemlje da se izgrade plinovodi i naftovodi iz Azerbajdžana, Kazahstana i Turkmenistana preko njezina teritorija kako bi se smanjila ovisnost kaspijskih zemalja o $\mathrm{Ru}-$ siji (Bolukbasi, 1998, 397). Tu nije posrijedi samo financijski interes od zarade na transportu nego i politički utjecaj koji se time stječe nad tim zemljama. Stari naftovodi i plinovodi iz sovjetskog razdoblja prolaze preko Rusije na zapad, dok se novi nastoje izgraditi prema Kini i Iranu, pa čak i preko Afganistana prema Indiji i Pakistanu (Rashid, 2001) (sl. 2 i sl. 3). To ugrožava utjecaj Rusije, a naročito kad se u to uključe i drugi sudionici poput SAD-a, Kine i Velike Britanije, koji nastoje preusmjeriti transport plina i nafte na vlastita tržišta te potiču kaspijske države da iskorištavaju svoje naftne i plinske izvore (Barylski, 1995, 218). Rusi-
Fig. 2 Existing and proposed oil pipelines in the part of Eurasia in question

SI. 2. Postojeći i predloženi naftovodi u dijelu euroazijskog prostora

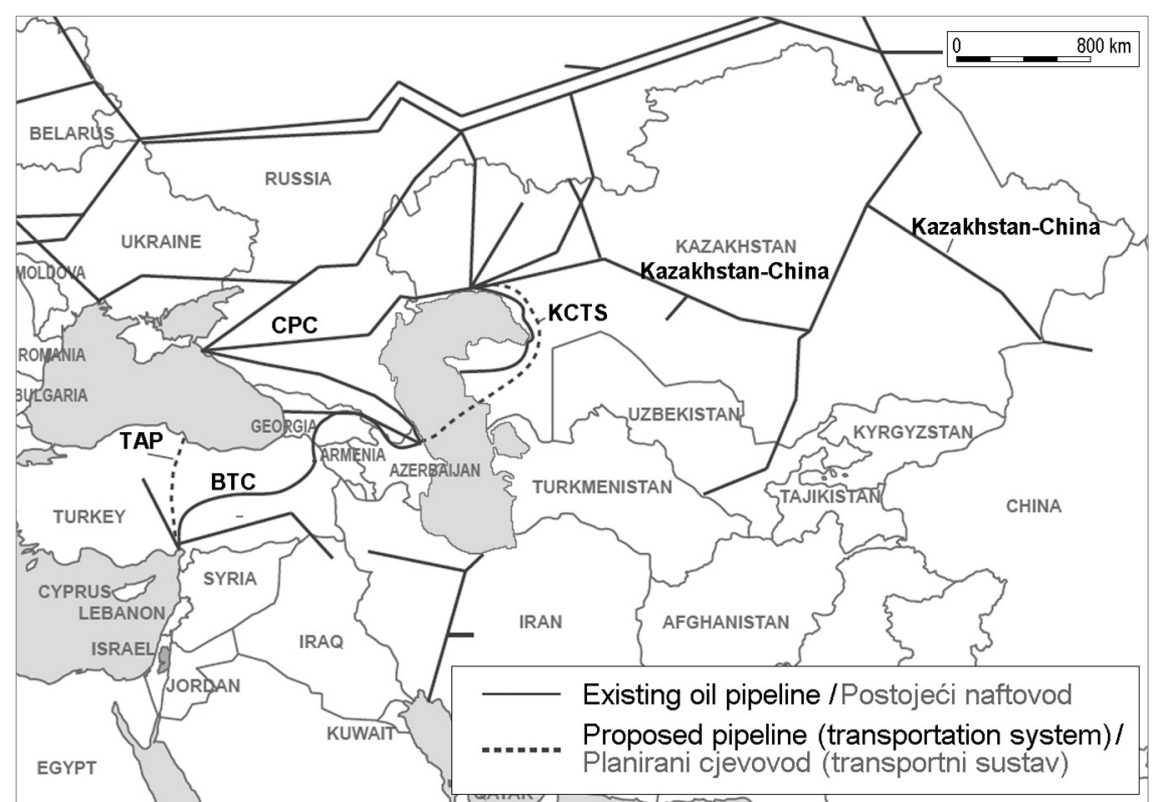

Source / Izvor: Chow and Hendrix, 2009, 41.
Geopolitical

Consequences of Resolving the

Legal Status of

the Caspian Sea:

Security and Energy Aspects

Geopolitičke posljedice rješavanja pravnog statusa Kaspijskog jezera: sigurnosni i energetski aspekti 
HRVATSKI

GEOGRAFSKI

GLASNIK

78/2,77-100 (2016.)

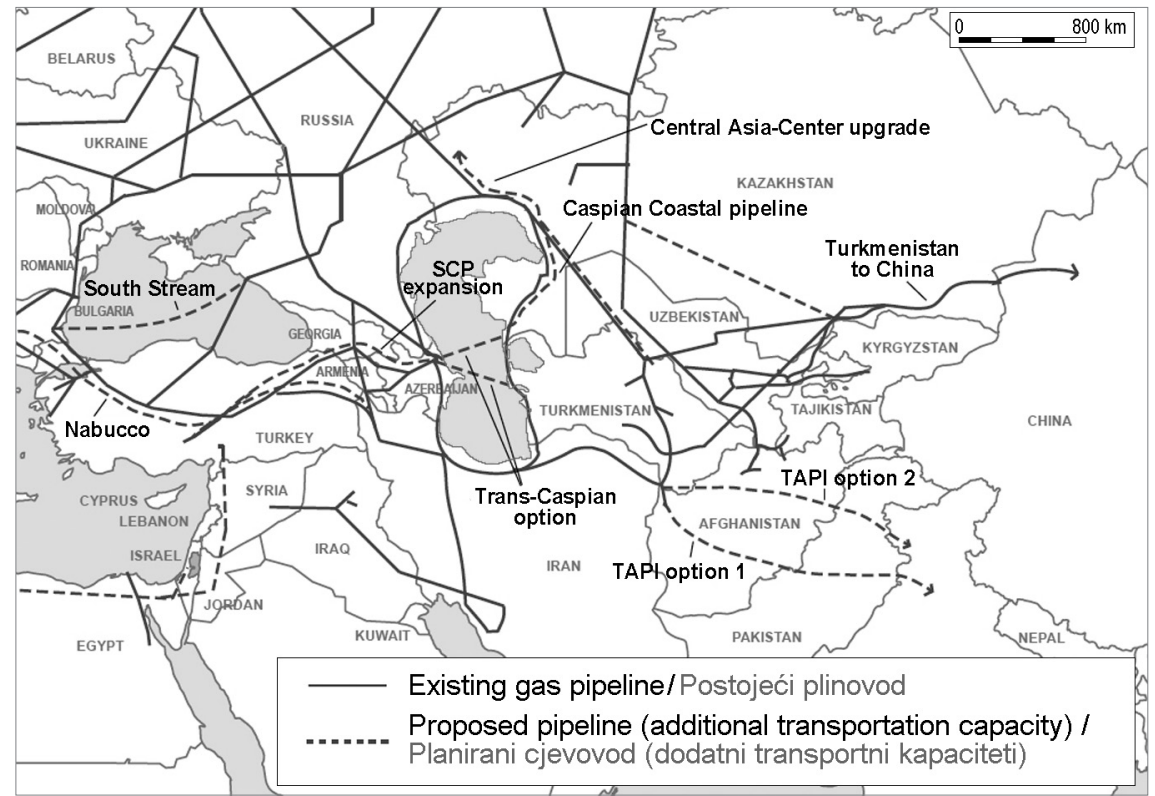

Fig. 3 Existing and proposed gas pipelines in the part of Eurasia in question

SI. 3. Postojeći i predloženi plinovodi u dijelu euroazijskog prostora

Source / Izvor: Chow and Hendrix, 2009, 41.

ki, 1995, 218). Therefore, in the past two decades, Russia has tried to keep control over the transport of oil and gas in its neighborhood (Kazantsev, 2008, 1073). One way they have tried to do so is through economic cooperation with these countries. Thereby, they have purchased gas from Turkmenistan and Kazakhstan, and sold it in Europe through their pipeline (Marketos, 2009). Russia has had great financial benefit from this arrangement, as it sells Central Asian energy at a much higher price than the one it pays to Central Asian countries (Marketos, 2009, 5). Therefore, the intentions of European countries to enter into the Caspian region because of oil and natural gas is a geopolitical problem, since it is at the same time entering into the area that Russia considers its "near abroad". To put it simply, "Russia's privileged position in Europe and the European neighborhood is highly linked to its ability to keep Caspian gas under its control" (Bilgin, 2009, 4487).

Caspian countries seek to take advantage of such Russian, Chinese, and Western interests in order to improve their respective positions, and achieve the greatest possible independence through contracts with various foreign companies that are willing to invest large sums of money in new construction or reconstruction of older oil and gas pipelines. Problems arise because of the increasing presence of external factors in Central Asia and the Caspian region, and ja je zbog toga u protekla dva desetljeća nastojala zadržati kontrolu nad transportom nafte i plina u svojem susjedstvu (Kazantsev, 2008, 1073). Jedan je od načina da to učini gospodarska suradnja s tim zemljama te je zbog toga i otkupljivala plin od Turkmenistana i Kazahstana i preko svojih plinovoda prodavala ga u Europi (Marketos, 2009). Ona je od toga imala i veliku financijsku korist jer srednjoazijske energente prodaje po znatno višoj cijeni od one po kojoj ga kupuje od tih zemalja (Marketos, 2009, 5). Zbog toga je namjera europskih zemalja da zbog nafte i plina uđu u kaspijsku regiju geopolitički problem jer je to ujedno i ulazak u područje koje Rusija smatra svojim bliskim susjedstvom. „Privilegirani položaj Rusije u Europi i europskom susjedstvu snažno je povezan s njezinom sposobnošću da drži kaspijski plin pod svojom kontrolom" (Bilgin, 2009, 4487).

Kaspijske zemlje nastoje iskoristiti takav ruski, kineski i zapadni interes kako bi unaprijedile svoj položaj i postigle što veću neovisnost putem sklapanja ugovora s različitim ruskim, američkim, kineskim i europskim kompanijama koje su spremne investirati velike svote novca u izgradnju novih ili rekonstrukciju starijih naftovoda i plinovoda. Problem nastaje zbog toga što sve veća prisutnost vanjskih čimbenika u Srednjoj Aziji i 
the worsening of relations between these countries due to their diverging interests. Some of them, such as Uzbekistan or Kazakhstan, seek to redirect foreign investment into their own territories at the expense of others. Rashid $(2001,220)$ argues that "statesmen of Central Asian countries have become obsessed with the planned oil and gas pipelines and their potential routes." He describes this "new great game" as a "the battle of the great powers for oil and influence in the Caspian region in which, besides the great powers, also participate neighboring countries Iran, Pakistan, Afghanistan and Turkey, the Central Asian countries and the most powerful of all players - oil companies" (Rashid, 2001, 222).

In recent years, however, there have been significant changes over the control of oil and gas pipelines. Since Russia did not have enough capital in the 1990s to participate in the development of the oil and gas industry in the region, Western companies have had an initial advantage which created dissatisfaction in Russia (Kubicek, 2013, 174). The initial dominance of Russia in the transportation of these fuels on the market in Europe and Asia suffered a blow because, as pointed out by Chow and Hendrix (2010, 32), "Russia lost an opportunity to integrate its logistical network with the global market by not accommodating the new political realities in Central Asia and the commercial requirements of Western companies operating in the Caspian"; which, in the end, prompted all foreign oil companies to find alternative routes to transport oil and gas to world markets (Chow and Hendrix, 2010, 32). One of the most popular alternative routes for energy exports from the Caspian Sea has been the BTC. It has been used since 2006 for the export of oil to the world market from Azerbaijan, Turkmenistan, and Kazakhstan via Azerbaijan, Georgia, and Turkey (Baku-Tbilisi-Ceyhan Pipeline). Russia saw the BTC as a conspiracy carried out with US support, in an order to remove Russia from the region (Karasac, 2002, 18-19), while Azerbaijan sees it as an instrument of its external independence in the oil and natural gas trade. Russia has answered this with plans to build new pipeline routes to Europe and China. In addition to the existing pipeline through Belarus and Ukraine, Russia has sought to build a Black Sea route to Bulgaria, Romania, and Greece. u kaspijskoj regiji te suprotstavljeni interesi pogoršavaju odnose među tim državama; neke od njih, poput Uzbekistana ili Kazahstana, nastoje preusmjeriti strane investicije na vlastito područje nauštrb drugih. Rashid ističe da su „državnici zemalja Srednje Azije postali opsjednuti planiranim naftovodima i plinovodima te njihovim potencijalnim rutama" (Rashid, 2001, 220). On opisuje „novu veliku igru” kao „bitku velikih sila za naftu i utjecaj u kaspijskoj regiji, u kojoj osim svjetskih velesila sudjeluju i susjedne zemlje Iran, Pakistan, Afganistan i Turska, same srednjoazijske zemlje i najmoćniji od svih igrača - naftne kompanije" (Rashid, 2001, 222).

U posljednjih nekoliko godina ipak je došlo do značajnih promjena u kontroli nad naftovodima i plinovodima. Budući da Rusija devedesetih nije imala dovoljno kapitala da sudjeluje u razvoju naftne i plinske industrije u regiji, zapadne kompanije imale su početnu prednost pred njom $(\mathrm{Ku}-$ bicek, 2013, 174), što je stvaralo dodatnu nervozu u toj zemlji. Početni dominantan položaj Rusije u transportu tih energenata na tržišta Europe i Azije doživio je veliki udarac jer je, kako ističu Chow i Hendrix, ona ,izgubila mogućnost da integrira svoju logističku mrežu s globalnim tržištem ne prilagođavajući se političkoj realnosti u Srednjoj Aziji i tržišnim zahtjevima zapadnih kompanija koje posluju na Kaspijskome moru" (Chow i Hendrix, 2010, 32), što je na kraju nagnalo sve strane naftne kompanije da pronađu alternativne rute za prijevoz nafte i plina na svjetska tržišta (Chow i Hendrix, 2010, 32). Jedna od najpoznatijih alternativnih ruta za izvoz energenata iz Kaspijskog jezera postao je BTC, kroz koji se od 2006. izvozi nafta iz Azerbajdžana, Turkmenistana i Kazahstana preko Azerbajdžana, Gruzije i Turske na svjetska tržišta (Baku - Tbilisi - Ceyhan Pipeline). Rusija je BTC vidjela kao urotu izvedenu uz američku podršku kako bi se izbacila s tog područja (Karasac, 2002, 18-19), dok ga Azerbajdžan vidi kao instrument vlastite vanjske neovisnosti u trgovini naftom i plinom. Rusija je nastojala uzvratiti time što planira izgraditi svoje nove plinovodne pravce prema Europi i Kini. Osim postojećih plinovoda preko Bjelorusije i Ukrajine, nastojala je izgraditi i crnomorski pravac prema $\mathrm{Bu}-$ garskoj, Rumunjskoj i Grčkoj. Aspects

Geopolitičke posljedice rješavanja pravnog statusa Kaspijskog jezera: sigurnosni i energetski aspekti 
Asian countries also recognized the need for the construction of new oil and gas pipelines in Central Asia and the Caucasus with the aim of faster transport of energy resources from the Caspian region. Pakistan and India are still only a potential market, while China has invested in the oil and gas industry in Kazakhstan and Turkmenistan, and oil and gas are being exported to the Chinese market via new pipelines (Heinrich and Pleines, 2015,19). Turkmenistan and Iran have built a pipeline to the north Iran, while Turkmenistan and Azerbaijan in turn want to build a Trans-Caspian pipeline that would link two countries and facilitate the export of Turkmen gas to the world market. Russia is opposed to this, but it does not openly express its views. It does that indirectly by demanding that the primary attention should be given to environmental criteria, and only after that to economic criteria (Moscow stands, 2015). Taking into account Russia's refusal to allow the entry of the West into Central Asia and the Caucasus, and trying as much as possible to put these countries under its own influence, Moscow's geopolitical interests in the region have actually been somewhat masked.

The policy of exploitation of oil and gas fields is different from the control of transit routes. The reason for this is that there is less flexibility; as routes of oil and gas pipelines can be adjusted, but the place where energy resources are exploited cannot be moved. The two largest Caspian countries are therefore at a disadvantage because they have significantly fewer proven reserves of oil and gas in their parts of the Caspian Sea. In this, the Astrakhan agreement of 2014 favors the three smaller countries because the largest reserves are located in their sectors. The Astrakhan Agreement, therefore, has had a positive effect on stability in the region because it establishes a kind of balance between Caspian countries; some of them are primarily focused on production and others on the transport, creating the necessity for mutual cooperation in order to maximize profit. The agreement also removed an obstacle to the further development of oil and gas fields that existed earlier. Proof of this can be seen in the behavior of Iran around the AIOC. Having rejected the participation of the Iranian oil company in the consortium, Iran, like Russia, threatened not to accept the Azerbaijani "Contract of the Century" of 1994 as binding until
Azijske zemlje također su uvidjele potrebu izgradnje novih naftovoda i plinovoda u Srednjoj Aziji i na Kavkazu kako bi se energetski resursi kaspijske regije mogli brže transportirati. Pakistan i Indija još su uvijek samo potencijalna tržišta, dok je Kina investirala u naftnu i plinsku industriju u Kazahstanu i Turkmenistanu te se novim naftovodima i plinovodima energenti izvoze na njezino tržište (Heinrich i Pleines, 2015, 19). Turkmenistan i Iran izgradili su plinovod prema sjeveru Irana, a Turkmenistan i Azerbajdžan pak žele izgraditi Transkaspijski plinovod koji bi povezivao dvije zemlje i omogućio izvoz turkmenistanskog plina na svjetsko tržište. Rusija se tome protivi, ali ne izravno iznoseći svoje stavove, nego zahtijevajući da se najveća pozornost da ekološkim kriterijima, a tek potom ekonomskim (Moscow stands, 2015). Imajući u vidu rusko odbijanje da dopusti Zapadu ulazak u Srednju Aziju i na Kavkaz te nastojeći što više približiti te zemlje svome utjecaju, takav stav Moskve zapravo maskira njezine geopolitičke interese na tom području.

Politika iskorištavanja naftnih i plinskih polja drugačija je od kontrole nad transportnim pravcima. Razlog tome jest manja fleksibilnost: dok se rute plinovoda i naftovoda mogu prilagođavati, mjesta na kojima se crpe energenti ne mogu se premještati. Dvije najveće kaspijske zemlje zbog toga su u nepovoljnijem položaju jer imaju puno manje dokazane rezerve nafte i plina na svojem dijelu Kaspijskog jezera. Astrahanski sporazum iz 2014. zbog toga je pogodovao trima manjim zemljama jer se u njihovim sektorima nalaze najveće rezerve. On stoga djeluje pozitivno na stabilnost u regiji jer uspostavlja svojevrsnu ravnotežu između kaspijskih zemalja: jedan dio njih ponajprije je usmjeren na proizvodnju, a drugi na transport te se stvara potreba za međusobnom suradnjom kako bi se maksimizirao profit. Taj sporazum također i uklanja prepreku za daljnji razvoj naftnih i plinskih polja koja je dosad postojala. Dokaz za to jest ponašanje Irana u vezi s AIOC-om. Nakon što je odbijeno sudjelovanje iranske naftne kompanije u tom konzorciju, Iran je, slično kao i Rusija, zaprijetio da neće prihvatiti azerbajdžanski „Ugovor stoljeća” iz 1994. kao 
it is resolved the legal status of the Sea (Bolukbasi, $1998,400)^{9}$. After 2014, and the subsequent negotiations on the status of the Caspian Sea, the argument for the lack of cooperation has disappeared.

\section{Conclusion}

By analyzing the negotiations on the legal status of the Caspian Sea, the militarization of the region, and the problem of exploiting and transporting oil and gas, this essay has confirmed the hypothesis that: in the modern era in which earnings from natural resources are crucial for the economic growth of many countries, the conclusion of a preliminary agreement about the legal status of the Caspian Sea in 2014 is a factor which stabilizes the region and has wider geopolitical consequences.

The conflict over the use and control of natural resources in the Caspian region, a quarter of a century after the collapse of the USSR, is not finished. The analysis of three key problems in the region shows that the Caspian Sea's oil and gas are its most important sources of wealth and the main cause of its instability - for several reasons. First, all three analyzed problems are linked because the inability to solve a single problem affects the ability to resolve the remaining two. The causal relationship between them is such that the legal status could be not arranged due to the many and varied interests surrounding the oil and gas and the role of the Caspian Sea in international relations. Different interests, connected with oil and gas, have prevented an agreement on the legal status, as each country has its own attitude about the issue of dividing the Sea. This directly affects the amount of resources that are accessible to each country for exploitation. The militarization of the Sea, however, is directly related to these two problems because the inability to reach agreement has had a negative impact on mutual trust among Caspian countries, which is why they are strengthening their fleets - in order to protect themselves and their resources. This causes shifting, on the part of Caspian countries, in their alliances to different world powers. These powers are, due to oil and gas resources or due their intention to be military present in the region, in- obvezujući sve dok se ne riješi pravni status jezera (Bolukbasi, 1998, 400). ${ }^{9}$ Nakon 2014. i daljnjih pregovora o statusu Kaspijskog jezera nestaje taj argument za izostanak suradnje.

\section{Zaključak}

Analizirajući pregovore o pravnom statusu Kaspijskog jezera, militarizaciju regije i problem iskorištavanja i transporta nafte i plina, ovaj rad potvrdio je hipotezu da je u suvremeno doba, u kojemu je zarada od prirodnih resursa presudna za gospodarski rast mnogih zemalja, sklapanje preliminarnog sporazuma o pravnom statusu Kaspijskog jezera iz 2014. čimbenik koji stabilizira regiju i ima šire geopolitičke posljedice.

Sukob oko iskorištavanja i kontrole prirodnih resursa u kaspijskoj regiji ni četvrt stoljeća nakon raspada SSSR-a nije završio. Analiza triju ključnih problema u regiji pokazuje da su Kaspijsko jezero i njegovo najvažnije bogatstvo nafta i plin uzrok nestabilnosti zbog nekoliko razloga. Prvo, sva tri analizirana problema povezana su jer nemogućnost rješavanja jednoga utječe na nerješavanje ostalih. Uzročno-posljedični odnos među njima takav je da se pravni status nije mogao dogovoriti zbog različitih interesa u vezi s naftom i plinom te ulogom Kaspijskog jezera u međunarodnim odnosima. Različiti interesi vezani uz naftu i plin sprečavali su postizanje sporazuma o pravnom statusu zbog toga što je svaka zemlja imala različit stav o tome kako bi se jezero trebalo podijeliti jer to utječe na količinu resursa koje će moći iskorištavati. Militarizacija jezera pak izravno je povezana s ta dva problema jer nemogućnost postizanja sporazuma negativno utječe na međusobno povjerenje kaspijskih zemalja, zbog čega one jačaju svoje jezerske flote htijući zaštititi sebe i svoje resurse. To izaziva okretanje dijela tih zemalja prema drugim svjetskim silama koje su zbog nafte i plina ili zbog namjere da budu vojno stacionirane u regiji zainteresirane za tu suradnju. No takav vanjski interes izaziva nezadovoljstvo
Geopolitical

Consequences of Resolving the

Legal Status of

the Caspian Sea:

Security and Energy Aspects

Geopolitičke posljedice rješavanja pravnog statusa Kaspijskog jezera: sigurnosni i energetski aspekti 
terested in this cooperation. But such external interest has resulted in the discontent of two most powerful countries of the Caspian - Russia and Iran, which want to close the sea to the outside world and thus preserve their dominance in the region.

The agreement of 2014 was the greatest achievement in relations among Caspian states over the past quarter century. It was a compromise where everyone had to let go of some of their requests, but they also achieved a considerable benefit, both in economic and in foreign policy terms. The economic gains consisted of the fact that they can now more easily determine which of the oil and gas fields in the region are theirs, and they can protect them more easily than before. The foreign policy benefits are the improvement of inter-Caspian relations and less need for further arming. Depending on their willingness to achieve further compromise these gains could be increased or decreased, which will affect the stability of the whole region. The biggest winner of the agreement is Russia, who achieved its goal of closing the region to western countries and the United States, and strengthened its influence in the "near abroad" of the Caucasus and Central Asia - where US military forces are not currently operating. Russia, at the same time, has expanded its influence further into the outside world, especially into the Middle East, to an extent which was not possible in the Soviet period; and has achieved close cooperation with Iran, which has become its base for military action in Syria, and potentially in any country with which Iran has borders. Such a change of geopolitical relations is not necessarily permanent, because all Caspian countries primarily seek to maximize their economic and security interests, and their cultural similarities are not crucial for their mutual relations. If a change in the balance of power between them or any new priorities in addition to security and economy occurs, the importance of the Astrakhan agreement of 2014 could be lessened. But, if the desire for a compromise becomes the dominant desire in their relations, the agreement could become the basis for further cooperation and stability in the region. The biggest problem is that the region is now a point of entry into the neighboring Middle East for Russia's military - a region that is very unstable and could potentially destabilize all regions in its neighborhood, including the Caspian. Solving problems in the Middle East is, therefore, a precondition for the stabilization of the wider area, including around the Caspian Sea. dviju najmoćnijih kaspijskih zemalja Rusije i Irana, koje žele zatvoriti jezero prema vanjskome svijetu i time očuvati svoj dominantni položaj u regiji.

Sporazum iz 2014. bio je najveći domet u odnosima među kaspijskim državama u proteklih četvrt stoljeća. To je bio kompromis u kojemu su sve one izgubile ponešto od svojih prijašnjih zahtjeva, ali su i dosta dobile, kako u gospodarskome tako i u vanjskopolitičkom smislu. Gospodarski dobitak sastoji se u tome što one sada mogu lakše utvrditi koja su njihova naftna i plinska polja u regiji te ih mogu lakše zaštititi. Vanjskopolitički dobitak tiče se poboljšanja njihovih međusobnih odnosa i manje potrebe za daljnjim naoružavanjem. Ovisno o njihovoj spremnosti za postizanje daljnjih kompromisa, ti dobici mogu se povećati ili smanjiti, što će utjecati i na stabilnost cijele regije. Trenutačno je najveća dobitnica $\mathrm{Ru}$ sija, koja je tim sporazumom ostvarila svoj cilj o zatvaranju regije za zapadne zemlje i SAD te ojačala svoj utjecaj u „bliskom susjedstvu” Kavkaza i Srednje Azije, koje više nije područje na kojem su stacionirane ili djeluju američke vojne snage. Ona je istodobno proširila svoj utjecaj u vanjskom svijetu, naročito na Bliskom istoku, u mjeri koja nije postojala još od sovjetskog razdoblja te je ostvarila blisku suradnju s Iranom, koji je postao njezino uporište za vojne akcije u Siriji i potencijalno u bilo kojoj zemlji s kojom on graniči. Takva promjena geopolitičkih odnosa nije nužno trajna jer sve kaspijske države prije svega nastoje maksimizirati svoje ekonomske i sigurnosne interese i na njih presudno ne djeluju njihove kulturološke sličnosti. Ako se promijeni odnos snaga među njima ili nastanu neki novi prioriteti uz sigurnosne i ekonomske, važnost astrahanskog sporazuma iz 2014. mogla bi se smanjiti. No prevlada li želja za kompromisom, taj bi sporazum mogao postati temelj za daljnju suradnju i stabilnost regije. Najveći je problem to što je ona trenutačno vojni ulaz Rusije u susjedni Bliski istok, koji je trajno nestabilan i može destabilizirati sve regije oko sebe, uključujući i kaspijsku. Rješavanje problema na Bliskom istoku jest dakle uvjet i za stabilizaciju širega područja, uključujući i ono oko Kaspijskog. jezera. 
Assanbayev, M. B. 2014: Geopolitics of Turkmenistan and Kazakhstan in the Casipan Region, u: The Caspian Sea Chessboard: Geo-political, geo-strategic and geo-economic analysis (ed. Frappi, C. and Garibov, A.), Center for Strategic Studies, Azerbaijan and Institute for International Political Studies, Italy, Baku and Milan, 143-163.

Bahgat, G., 2002: Splitting Water: The Geopolitics of Water Resources in the Caspian Sea, SAIS Review of International Affairs 22 (2), 273-292.

Barylski, R. V., 1995: Russia, the West, and the Caspian Energy Hub, Middle East Journal 49 (2), 217-232.

Bilgin, M., 2009: Geopolitics of European natural gas demand: Supplies from Russia, Caspian and the Middle East, Energy Policy 37 (11), 4482-4492.

Bolukbasi, S., 1998: The Controversy over the Caspian Sea Mineral Resources: Conflicting Perceptions, Clashing Interests, Europe-Asia Studies 50 (3), 397-414.

Butler, W. E., 1969: The Soviet Union and the Continental Shelf, The American Journal of International Law 63 (1), 103-107.

Chow, E. C., Leigh E. H., 2010: Central Asian Pipelines: Fields of Dreams and Reality. The National Bureau of Asian Research, NBR Special Report, 23 (1), 29-42.

Flanagan, S. J., 2013: The Turkey-Russia-Iran Nexus: Eurasian Power Dynamics, The Washington Quarterly 36 (1), 163-178.

Garibov, A., 2014: Militarization of the Caspian Sea: Naval Arms Race and Conflicting Interest, u: The Caspian Sea Chessboard: Geo-political, geo-strategic and geo-economic analysis (ed. Frappi, C. and Garibov, A.), Center for Strategic Studies, Azerbaijan and Institute for International Political Studies, Italy, Baku and Milan, 41-58.

Hafeznia, M. R., Pirdashti, H., Ahmadipour, Z., 2016: An expert-based de- cision making tool for enhancing the consensus on Caspian Sea legal regime, Journal of Eurasian Studies 7 (2), 181-194.

Heinrich, A., Pleines, H., 2015: Mixing geopolitics and business: How ruling elites in the Caspian states justify their choice of export pipelines, Journal of Eurasian Studies 6 (2), 107-113.

Karasac, H., 2002: Actors of the new "Great Game", Caspian oil politics, Journal of Southern Europe and the Balkans Online 4 (1), 15-27.

Kazantsev, A., 2008: Russian Policy in Central Asia and the Caspian Sea Region, Europe-Asia Studies 60 (6), 1073-1088.

Klare, M. T., 2005: Krv i nafta: Ovisnost o uvoznoj nafti $i$ nacionalna sigurnost, Tiskara Znanje, Zagreb.

Kubicek, P., 2013: Energy politics and geopolitical competition in the Caspian Basin, Journal of Eurasian Studies 4 (2), 171-180.

Laruelle, M., Peyrouse, S., 2009: The Militarization of the Caspian Sea: "Great Games" and "Small Games" Over the Caspian Fleets, China and Eurasia Forum Quarterly 7 (2), 17-35.

Makili-Aliyev, K., 2014: Caspian Sea and Its International Legal Status, u: The Caspian Sea Chessboard: Geo-political, geo-strategic and geo-economic analysis (ed. Frappi, C. and Garibov, A.), Center for Strategic Studies, Azerbaijan and Institute for International Political Studies, Italy, Baku and Milan, 27-39.

Marketos, T., 2009: Eastern Caspian Sea Energy Geopolitics: A Litmus test for the U.S. - Russia - China Struggle for the Geostrategic Control of Eurasia, Caucasian Review of International Affairs 3 (1), 2-19.

Megoran, N., 2004: The critical geopolitics of the Uzbekistan-Kyrgyzstan Ferghana Valley boundary dispute, 1999-2000, Political Geography 23 (7), 731-764.

Mehdiyoun, K., 2000: International law and the dispute over ownership of oil and gas resources in the Caspian Sea, Reprinted from The American Journal of International Law 94 (1).

Peimani, H., 2009: Conflict and Security in Central Asia and the Caucasus, ABC-CLIO, Santa Barbara, Denver, Oxford.

Rabinowitz, P. D., Yusigov, M. Z., Arnoldi, J., Hakim, E., 2004: Geology, Oil and Gas Potential, Pipelines, and the Geopolitics of the Caspian Sea Region, Ocean Development \& International Law 35 (1), 19-40.

Rashid, A., 2001: Talibani: Islam, nafta i nova velika igra u Srednjoj Aziji, Tamaris, Zagreb.

Rubin, B. R., 2006: Central Asia and Central Africa: Transnational Wars and Ethnic Conflicts, Journal of $\mathrm{Hu}^{-}$ man Development 7 (1), 5-22.

Sadri, H. A. 2012: Iran and the Caucasus States in the 21st Century: A Study of Foreign Policy Goals and Means, Journal of Balkan and Near Eastern Studies 14 (3), 383-396.

Thorun, C., 2009: Explaining Change in Russian Foreign Policy: The Role of Ideas in Post-Soviet Russia's Conduct towards the West, Houndmills, Palgrave Macmillan.

Uibopuu, H., 1995: The Caspian Sea: A Tangle of Legal Problems The World Today 38 (6), 119-123.

Winstone, R., Young, R., 2005: The Caspian Basin, energy reserves and potential conflicts, House of Commons Library, London.

Zimnitskaya, H., Geldern, J. v., 2011: Is the Caspian Sea a sea; and why does it matter?, Journal of Eurasian Studies 2 (1), 1-14.

Zonn, I. S., 2005: Economic and International Legal Dimensions, u: The Caspian Sea Environment (ed. Kosarev, A. N., Kostianoy, A. G.), Springer-Verlag, Berlin and Heilderberg, 243-256.

Žirinovski, V., 1994: Posljednji skok na jug, Mladost, Zagreb.
D. Boban

K. Lončar

Geopolitical

Consequences

of Resolving the

Legal Status of

the Caspian Sea:

Security and Energy Aspects

Geopolitičke posljedice rješavanja pravnog statusa Kaspijskog jezera: sigurnosni i energetski aspekti

\section{Literature} Literatura 
Aryan, H., Caspian Sea States On Course For Naval Arms Race, http://www.rferl.org/content/caspian_states_on_course_for_naval_arms_race/24278751.html (26.10.2015)

Bahman, A. D., 2004: Militarization of the Caspian Sea, http://www.payvand.com/news/04/apr/1107.html (29.10.2015)

Baku-Tbilisi-Ceyhan Pipeline, http://www.bp.com/en_az/caspian/operationsprojects/pipelines/BTC.html (05.05.2015)

Differences on using Caspian Sea bed remain, http://tass.ru/en/world/821319 (02.11.2015)

Caspian Summit in Astrakhan - A Major Step Forward, 2014 http://www.islamnews.ru/news-435312.html (29.10.2015)

Kazakhstan Navy, http://www.globalsecurity.org/military/world/centralasia/kazak-navy.htm (03.05.2015)

Kazakhstan's parliament ratifies agreement with Turkmenistan on Caspian Sea delimitation, http://tass.ru/en/world/803774 (02.11.2015)

Kucera, J., 2012: The Great Caspian Arms Race: Inside the petro-fueled naval military buildup you've never heard of: It's Russia versus Iran, with three post-Soviet states -- and trillions of dollars in oil -- in the middle, http://foreignpolicy.com/2012/06/22/the-greatcaspian-arms-race/ (29.10.2015)

Moscow stands against unilateral actions for Trans-Caspian gas pipe construction, http://tass.ru/en/economy/799657 (02.11.2015)

Overview of oil and natural gas in the Caspian Sea region, http://www.eia.gov/beta/international/regions-topics.cfm?RegionTopicID $=$ CSR (17.06.2015)

Parkhomchik, L., 2015: New Phase of the Caspian Sea Delimitation, http://eurasian-research.org/?q=en/research/comments/international-relations/new-phase-caspian-sea-delimitation (05.11.2015)

Press statement following the Fourth Caspian Summit, http://en.kremlin.ru/events/president/transcripts/46689 (02.11.2015)

Russia, Kazakhstan sign Caspian Sea agreement, http://tass.ru/en/economy/829089 (02.11.2015)

Socor, V., 2005: Russia Pressing for Exclusionary Naval Grouping in Caspian Sea, Eurasia Daily Monitor 2 (198), http://www.jamestown.org/single/?tx_ttnews\%5Btt_news\%5D=31015\&no_cache=1\#.VYG3C_ntmkp (02.05.2015)

United Nations Convention on the Law of the Sea and Final Act of the Third United Nations Conference on the Law of the Sea with Annexes I-VII and with Annex and the Agreement Relating to the Implementation of Part XI of the United Nations Convention on the Law of the Sea of December 10 th 1982

Konvencija Ujedinjenih naroda o pravu mora i Završni akt Treće konferencije Ujedinjenih naroda o pravu mora s Prilozima I.-VII. i Dodatkom i Sporazum o primjeni XI. dijela Konvencije Ujedinjenib naroda o pravu mora od 10. prosinca 1982., Narodne novine, Međunarodni ugovori broj: 9/2000, http://narodne-novine.nn.hr/clanci/medunarodni/328160.html (03.05.2015)

Authors

Autori

\section{Davor Boban dboban@fpzg.hr}

Assistant Professor, University of Zagreb, Faculty of Political Science, Lepušićeva 6,

10000 Zagreb, Croatia

Karlo Lončar

loncar.karlo@gmail.com

M. A. in Political Science, M.A. student at Central European University, Nationalism Studies Department,

1011 Budapest, Hungary 